INTER-AMERICAN DEVELOPMENT BANK

BANCO INTERAMERICANO DE DESARROLLO (BID)

RESEARCH DEPARTMENT

DEPARTAMENTO DE INVESTIGACIÓN

WORKING PAPER \#58I

\title{
The Elusive Costs of Sovereign Defaults
}

\author{
BY \\ EDUARDO LEVY-YEYATI* \\ UGO PANIZZA** \\ * Universidad Torcuato di Tella \\ AND WORLD BANK \\ * * INTER-AMERICAN DEVELOPMENT BANK
}

NOVEMBER 2006 


\section{Cataloging-in-Publication data provided by the Inter-American Development Bank \\ Felipe Herrera Library}

Levy Yeyati, Eduardo.

The elusive costs of sovereign defaults / by Eduardo Levy-Yeyati, Ugo Panizza.

p. cm.

(Research Department Working paper series ; 581)

Includes bibliographical references.

1. Finance, Public. 2. Default (Finance). 3. Debts, Public. I. Panizza, Ugo. II. InterAmerican Development Bank. Research Dept. III. Title. IV. Series.

HJ141 .L39 2006

336 L39-----dc22

(C)2006

Inter-American Development Bank

1300 New York Avenue, N.W.

Washington, DC 20577

The views and interpretations in this document are those of the authors and should not be attributed to the Inter-American Development Bank, or to any individual acting on its behalf.

This paper may be freely reproduced provided credit is given to the Research Department, InterAmerican Development Bank.

The Research Department (RES) produces a quarterly newsletter, IDEA (Ideas for Development in the Americas), as well as working papers and books on diverse economic issues. To obtain a complete list of RES publications, and read or download them please visit our web site at: http://www.iadb.org/res. 


\begin{abstract}
*
Few would dispute that sovereign defaults entail significant economic costs, including, most notably, important output losses. However, most of the evidence supporting this conventional wisdom, based on annual observations, suffers from serious measurement and identification problems. To address these drawbacks, we examine the impact of default on growth by looking at quarterly data for emerging economies. We find that, contrary to what is typically assumed, output contractions precede defaults. Moreover, we find that the trough of the contraction coincides with the quarter of default, and that output starts to grow thereafter, indicating that default episode seems to mark the beginning of the economic recovery rather than a further decline. This suggests that, whatever negative effects a default may have on output, those effects result from anticipation of a default rather than the default itself.
\end{abstract}

\footnotetext{
* We would like to thank Eduardo Cavallo and other participants in the December 2005 IPES pre-conference, and we wish to thank Mariano Alvarez for excellent research assistance. The views expressed in this paper are the authors' and do not necessarily reflect those of the Inter-American Development Bank.
} 
"Hell, the last thing I should be doing is tell a country we should give up our claims. But there comes a time when you have to face reality."

"The problem historically has not been that countries have been to eager to renege on their financial obligations, but often too reluctant. ${ }^{1}$ "

\section{Introduction}

As conventional wisdom has it, a sovereign's unilateral decision to stop servicing its debt carries important and persistent economic costs. This is what is assumed (either explicitly or implicitly) by the sovereign debt literature as a government's main incentive to honor its obligations. ${ }^{2}$ In this paper, we argue that using higher-frequency data yields a starkly different message. In particular, we show that defaults have no significant negative impact on successive output growth and, if anything, mark the final stage of the crisis and the beginning of economic recovery.

The empirical literature has looked at the relationship between default and GDP growth mainly in three ways: (i) output regressions directly controlling for default events; (ii) tests of the effect of (current and past) defaults on access to the international credit market (more specifically, borrowing costs); and (iii) tests of the effects on international trade (either due to the drying up of trade credit or due to the implementation of trade sanctions). In all three cases, the costs specifically associated with default (that is, in excess of those related to the ongoing crisis, or to the memory of a recent crisis) are difficult to identify. While Ozler (1993) found that defaults in the 1930s were associated with an increase in spreads of approximately 20 basis points 40 years later, more recent work found that the effect of default on spreads is short-lived (Ades et al., 2000; Borensztein and Panizza, 2005a). Focusing on the trade cost of defaults Rose (2002) found that countries that defaulted on official (Paris Club) debt trade less with defaulted

\footnotetext{
${ }^{1}$ The first quote is from an unnamed financial industry official; the second comes from a memo prepared by the Central Banks of England and Canada. Both are taken from Blustein (2005, pp. 163 and 102).

${ }^{2}$ Sturzenegger (2004) finds a strong (albeit short-lived) negative contemporaneous effect on growth, and substantial output losses associated with defaults, a result confirmed by Borenzstein and Panizza (2005a). Both studies are based on annual observations.
} 
countries, while Borensztein and Panizza (2005b) find that export-oriented industries tend to suffer more in the aftermath of a default, though the effect is transitory. ${ }^{3}$

However, all these are indirect costs, and growth regressions should be the main piece of evidence supporting the view that defaults have been costly. It is easy to see, though, how existing results may be misleading. Consider, for instance, two recent default episodes: Ecuador and Argentina. Judging from annual data, Ecuador contracted by 6 percent in 1999 (the default year), and Argentina's output declined by 12 percent in 2002 (the official date of the Argentinean default was December 2001). However, a closer look at the data reveals a starkly different picture. Once the quarterly evolution of GDP is taken into account, the default event appears to coincide not with the period of more pronounced contraction but rather with the beginning of the recovery (Figure 1). Quarterly and annual data yield different messages because GDP is an average, and high-frequency shocks tend to spill over to the subsequent period when output is reported at a lower frequency. Thus, the sharp GDP contraction in Argentina in late 2001 is largely registered as an output decline in 2002, despite the fact that the economy started to grow early that year. As the figure shows, the same could be said for the large defaults of the 1990s, such as those by Indonesia, Russia, Ukraine and Uruguay (indeed, recovery was already underway in the latter at the time of default).

Related with the previous point, a key reason why a look at quarterly data is in order is that default, rather than a strategic decision to withhold the surplus of the bonanza, as painted in the traditional sovereign debt literature (e.g., Eaton and Gersovitz, 1981), tends to reflect financial constraints in the midst of economic crises. It is easy to see how this poses a serious identification problem, namely, disentangling the effect of the default decision from that of the crisis per se on economic performance-and how one could spuriously attribute the peak of the crisis to the default event, capturing the incidence of financial distress on the decision to default, rather than the impact of default on financial and economic performance. Although the use of higher-frequency data does not fully solve this problem, it help to provide a more accurate picture. In particular, it shows more clearly the timing of the default in the context of the evolving crisis and sheds light on the timing of the events.

\footnotetext{
${ }^{3}$ Borensztein and Panizza (2005a) explore a fourth channel: the effect of defaults on the propensity to suffer a banking crises (presumably due to the fiscal exposure of the banking sector). They find that defaults do not present a systematic leading pattern (although this does not deny that expectations of a debt default could trigger a bank run).
} 
With this in mind, in this paper we conduct a simple exercise: We replicate the standard tests of the effect of default on growth and output using quarterly data for emerging economies. The use of quarterly data allows us to date the default properly, to capture the evolution of output more accurately, and to control for slowly moving fundamentals to better isolate the effect of default.

We restrict our attention to a particular type of default, namely, default on debt with private international investors. For this reason, we focus on emerging economies, which by definition comprise globally integrated economies with a minimum volume of cross-border debt. The emerging class provides a reasonably homogenous group exhibiting comparable external vulnerability to capital account reversals (Sudden Stops) and, possibly, the highest propensity to suffer from default episodes. ${ }^{4}$

Moving from yearly to quarterly data entails properly dating the default, which poses non-trivial problems. Take, for instance, the recent events in Argentina. While Standard and Poor's gave a selective default rating in the last quarter of 2001 after a quasi-voluntary debt exchange, most observers argue that a more accurate date of the default on international bonds is January 2002, when the default was actually announced. ${ }^{5}$

In this paper, we compile a quarterly database on emerging market defaults and run panel growth regressions controlling for crisis variables, both annual (to check consistency with previous results reported in the literature) and quarterly. We include several leads and lags to ensure that the results are not driven by dating errors. We find that, when we look at quarterly data, growth rates in the post-default period are never significantly lower than in normal times. Moreover, the evidence indicates that, contrary to what is typically assumed, the output contractions often attributed to defaults actually precede them. Indeed, defaults mark the inflection point at which output reaches its minimum and starts to recover.

This should not be interpreted as proof that defaults in general do not matter. On the contrary, much in the way of a standard liquidity run, most of the financial distress that precedes the default decision may be due to its anticipation. However, our findings have distinct

\footnotetext{
${ }^{4}$ Extending this exercise to other countries is not straightforward. There are no recent defaults by industrial countries, and their inclusion as a control group is questionable. On the other hand, while there are defaults on debt with foreign banks in non-emerging, low income economies, availability of quarterly output data is in these case virtually null.

${ }^{5}$ Importantly, Argentina had not missed a payment before that date. This example, however, shows that dating errors are only magnified when we look at annual data, yet another reason to go quarterly.
} 
implications from a policy perspective. If defaults were costly a posteriori, the decision to default should weigh these costs against the fiscal effort needed to service the debt. However, once the default is anticipated (and its concomitant cost brought forward) by the market, the formal decision to stop servicing the debt entails no tradeoff and is therefore optimal (and even overdue).

The paper proceeds as follows. Section 2 describes the data, and Section 3 presents the main empirical results. Finally, Section 4 discusses the implications of our findings for the optimal timing of default and concludes.

\section{Section 2. The Data}

Table 1 reports the summary statistics. Table A1 in the Appendix provides a definition of our variables and the sources of data, and Table A2 lists all countries and periods covered in the analysis.

Table 2 lists the default episodes in our sample. The tests below do not include all 23 default episodes listed in the table because some of them occurred within a relatively short window and should be considered as spin-offs of the previous episode; their inclusion may bias the results against finding a significant default cost. For this reason, we exclude default episodes that happen within three years of the previous default (which leaves out the Indonesian defaults of 2000 and 2002). Furthermore, we only include default on private lenders and hence exclude the Pakistani default on Paris Club debt of 1997. As a consequence, our working sample includes 20 default episodes. Ten of these episodes took place in the 1980s and mostly concerned international bank loans. The remaining 10 took place in the last 15 years and mostly involved sovereign bonds.

\section{First Impressions}

Figure 2 illustrates how the evolution of GDP around default episodes varies when we move from annual to quarterly observations. The first panel shows GDP levels over a 6-year window centered on the default period for a full sample of emerging and non-emerging economies. ${ }^{6}$ The $\mathrm{X}$ axis is defined in event time, where 0 indicates the year of the default episode, -3 indicates

\footnotetext{
${ }^{6}$ Quarterly GDP levels are seasonally adjusted (excluding the default period) and normalized by the mean over the window.
} 
three years before the episode and 3 indicates three years after the event. This shows that GDP starts decreasing two years before the event and keeps decreasing (albeit, at a slower rate) in the following three years, a picture broadly consistent with the output cost of defaults identified in panel growth regressions that use annual data.

In the second panel, we repeat the exercise for our emerging market sample. As before, we see a clear drop in GDP in the three years before the default episode, whereas now the output remains stable and close to its minimum in the following three years. Again, the declining trend precedes the default event, but growth remains either negative or close to zero thereafter.

The third panel replicates the exercise once more, this time for the emerging market sample and using quarterly data (now the $\mathrm{X}$ axis is measured in quarters). Now, we find a slightly negative trend in the three years preceding the default episode combined with a steep drop in the last three quarters of the pre-episode window. On the other hand, while GDP still falls in the quarter after the event, the trend reverses immediately thereafter to a quick and steady recovery to above pre-crisis levels. Thus, at least at this preliminary graphic level, going from annual to quarterly data appears to change the message in a significant way.

\section{Results}

Figure 2 provides suggestive evidence that the output costs of default are hard to find when measured using quarterly data, but does not amount to a formal test. Such a test is reported in this section. As before, we move gradually from the existing literature to our preferred specification.

\subsection{Default and Growth}

Table 3 estimates the cost of default using a standard growth regression based on yearly data. In columns 1 to 3, we take the specification adopted by Sturzenegger (2004) and Borensztein and Panizza (2005a) and add country fixed effects. In column 1, we capture the cost of default with a dummy variable that takes a value of 1 in the year in which a country defaults and zero otherwise (def). The regression shows the standard results: defaults are associated with a drop in growth of approximately 3 percentage points and the coefficient is highly significant. Column 2 also includes a dummy taking a value of 1 in the year that precedes the episode (def T-1) and a dummy taking a value of 1 in the year that follows the episode $(\operatorname{def} T+1)$. We find negative coefficients for both dummies, although only the lead (def T-1) is statistically significant. Column 3 replicates column 2, this time dropping the year of default episode, and finds identical 
results. In columns 4 to 6 , we run the same regressions without the control variables as an intermediate step towards our quarterly specification, which excludes controls due to data availability. Now def $T+1$ becomes statistically significant and large, indicating that growth in the year after default is 2 percentage points lower than in tranquil times. Other than that, the results are strikingly similar to the previous ones. The same applies to column 7 (where we replicate the specification of column 4 for the sample of column 1), and to columns 8 to 10 (where we run similar regressions for our emerging market sample). Results are virtually unchanged in all cases. In sum, based on annual data, during the three-year window around default, growth rates appear to be significantly (and substantially) lower than average-although, judging from the value of the coefficients, there is no indication that the decline accelerates after the actual default event.

Reassured by the robustness of the previous results to sample and specification changes, in Table 4 we repeat the exercise using quarterly GDP data. Column 1 includes only two regressors: a dummy variable taking value 1 in the default quarter and a market pressure index along the lines of Kaminsky and Reinhart (1999). The coefficient of the default dummy is negative and very large, suggesting that at the time default materializes, (quarterly) growth is a hefty 2.8 percent lower than in normal times. As expected, the market pressure variable is also negative and statistically significant. ${ }^{7}$ Column 2 adds dummies for the quarters that precede and follow the default event: unlike in the previous table, growth is now significantly lower in the quarter before, but not in the quarter after default. The same message is delivered when we include dummies for two and three periods before and after default (columns 3 and 4), and when we use two dummies to indicate the corresponding leads and lags (columns 5 and 6). In particular, growth is always significantly lower in the quarters leading to default but not in the quarters following default (we report the joint test of leads and lags at the bottom panel of the table).

Thus, a simple comparison of Tables 3 and 4 suggests that default materializes when the crisis are already underway: the negative link revealed by annual data simply captures the fact that defaults tend to occur in the context (and often as a result) of a crisis.

\footnotetext{
${ }^{7}$ Dropping this variable or including a variable measuring changes in the real exchange rate does not affect our results.
} 
Quarterly data may be more sensitive to (autocorrelated) measurement error that tends to be corrected over time. However, the results are unaltered when we re-run the regressions including the lagged dependent variable (Table 5). In turn, in Table 6, we control for countryyear fixed effects to capture the evolution of country-specific fundamentals at an annual frequency. As such, this test encompasses all annual variables typically used in standard specifications, including a crisis year dummy. The fact that the coefficients are never statistically significant provides further indication that, once the crisis is controlled for, default does not exert any visible influence on output. ${ }^{8}$

Table 7 explores the pre- and post-default periods in more detail by narrowing the estimation window to six-year period centered around the default event. The results are again unchanged. Table 8, in turn, explores the role of outliers (of particular relevance given the relatively small number of events in our sample) by running the regression of Table 4, column 2 dropping one country at a time. The table, which highlights extreme values for the coefficients and t-statistics, shows that the contemporaneous effect ranges between -1.79 and -2.88 and that it is always statistically significant. The effect at T- 1 ranges between -2.17 and -3.53 and is statistically significant in 13 out of 14 regressions (when we exclude Peru, the p-value is 0.12 ). By contrast, the effect at $\mathrm{T}+1$ ranges between -0.27 and -1.79 and it is never statistically significant (we obtain the lowest p value, 0.14, when we exclude Pakistan). Again, leads (but not lags) help explain the evolution of output.

Table 9 presents a different look at the evidence that tests the intuition provided by Figure 1: defaults mark the start of the recovery. To do that, we run an event-study like test that compares cumulative growth rate before and after the default event for different windows centered on the default quarter (which is dropped for the purposes of this computation). ${ }^{9}$ In this way, we want to confirm not only that output trend declines before the actual default takes place, but also that the declining trend is attenuated and even reverts after default. The results strongly support this hypothesis: cumulative growth goes from negative to positive, and the difference between growth rates before and after increases (Figure 3) to become significant as the window widens. Default represents, rather than a trigger, the turning point of the crisis, possibly due to

\footnotetext{
${ }^{8}$ The coefficients should be interpreted here as the deviation form the average growth rate in the year of default, and not as the deviation from the average growth rate in normal times.

${ }^{9}$ Specifically, setting $\mathrm{t}=0$ for the default quarter, DGDP(-s) $=[$ GDP $(-1) / G D P(-s)]-1$, and $\operatorname{DGDP}(+s)=$ [GDP(s)/GDP(+1)]-1.
} 
non-trivial costs of avoiding default and to the fact that most of the consequences of default are typically reflected in the markets before the decision is made official.

\subsection{Growth-Inducing Defaults?}

The finding that defaults have been followed by periods of economic recovery should not be mistaken as prima facie evidence of causality - much in the same way as the correlation between default and annual growth should not be mistaken as saying that defaults are costly. A simple inspection of Figure 1 suggests that, to the extent that larger recessions are followed by steeper recoveries, the benign post-default outcome may be simply reflecting the association of defaults with particularly deep economic downturns.

Indeed, Beaudry and Koop (1993) have shown that output expansions depend positively on the "current depth of recession" (CDR), defined as the gap between current level of output and its historical maximum. More generally, a growing body of literature has highlighted the nonlinear nature of the business cycle and, in particular, the fact that growth rates depend positively on the depth of the current output gap..$^{10}$

We examine whether this argument can explain the finding of "growth-inducing defaults" in two steps. First, we document that defaults are indeed associated with larger than average recessions (note that so far, we have only documented an association between recessions and defaults - more precisely, that the latter are typically preceded by the former-but not that the fact that recessions are more pronounced prior to default events). Second, we rerun the baseline regressions of Table 4 controlling for the current depth of the recession, captured by Beaudry and Koop’s (1993) CDR variable, to see whether the link between defaults and growth is due to the omission of the recession depth variable.

Table 10 reports the results from the first step, showing that the depth of the recession is significantly larger for recessions leading to debt defaults. In the table, we first compare the maximum recession depth in the absence of default for the whole sample, with the maximum CDR reached in recessions that coincided with default events. As the means test indicates, recessions are a significant 3 percent deeper during default episodes. The difference is even larger when we restrict attention to countries that defaulted at least once in the period under

\footnotetext{
${ }^{10}$ The underlying assumption is that, because of the excess capacity during the contractionary phase of the cycle, positive real shocks will have more persistent effects than negative shocks. See also Hamilton (1989), Jansen and Oh (1999), and Neftci (2001).
} 
study: for defaulters, recessions have been nearly twice as deep when they ended in default than otherwise. The same conclusion can be reached by looking at defaulters individually: pre-default recessions are always deeper (and often significantly so).

Table 11, in turn, replicates the baseline regressions of Table 4, including the CDR variable to test whether the expansionary effect of defaults can be attributed to the larger depth of the preceding recessions. As expected, we find that CDR has a positive and statistical significant effect on growth, which is robust to the inclusion of the lagged dependent variable (which replicates Beaudry and Koop’s (1993) specification for the U.S.). ${ }^{11}$ More to the point of our test, including the CDR variable does not alter our baseline result. First of all, we find that the leading effect of the crisis remains virtually unaltered (negative and statistically significant). Second, we find that including CDR and explicitly controlling for the effect of excess capacity somewhat reduces the post-default recovery documented in Table 4 (for instance, the coefficient at def $\mathrm{T}+1$ in Reg 2 goes from 1.1 to 0.4 ), but the coefficients for the post-default dummies remain positive and insignificant. All this points out that our previous results were not driven by the fact that we were not controlling for differences in the depth of the recession.

\subsection{Default and Growth in the Long Run}

Default may not have immediate effects on output, but may exert its influence over the long run, either through lower investment or reduced access to capital markets. ${ }^{12}$ Because of that, the analysis in this paper would not be complete without a look at the connection between default episodes and the evolution of long run growth.

We look at this issue in two ways. First, we compare growth rates before and after the event with the log linear trend growth. More precisely, we divide the defaults in our sample into three groups, according to whether post-default growth was below pre-default growth, above predefault growth but below long-term growth, and above long-term growth. Table 12 reports the result. As can be seen, whereas growth was stronger after default in 70 percent of the cases (in line with our previous findings), it exceeded long-term growth in 50 percent of the cases, suggesting that default, on average, does not deteriorate growth prospects.

\footnotetext{
${ }^{11}$ Interestingly, the coefficient for our developing sample is roughly twice as large as the one found for the U.S., possibly as a combination of nonlinear output gap effects and deeper recessions.

${ }^{12}$ While the evidence on the effect of default on access to finance as measured by its cost (specifically, the sovereign risk premium) is mixed at best (see Borenzstein and Panizza, 2005a), there is evidence that defaults may affect access through a reduced volume of funds (Levy Yeyati, 2006).
} 
In Table 13, we look at the same issue from a different angle. Exploiting the variability of HP-filtered long-term growth, we rerun the baseline regressions in Table 4, replacing the growth rate with the long-term growth rate (computed country by country over the full sample period). As can be seen, the decline in trend output that characterizes the period surrounding default precedes the default event, and it does not appear to elicit an additional negative impact ex-post. Thus, there seems to be no negative effect on the long-run output immediately after the default event. Indeed, long-run growth appears to increase in the post-default period, as illustrated by Figure 4, where we compare average HP-filtered output before and after the event. While the difference in trends is not significant (as the one standard deviation intervals indicate), the figure further confirms that defaults do not seem to exert a negative effect on output over the long run.

\subsection{Default and Unemployment}

Many observers would agree that, once income distribution is taken into account, unemployment may be a more important—and persistent—determinant of social welfare than output growth (Pernice and Sturzenegger, 2004). On the other hand, one would expect unemployment and real growth to be closely correlated, so that the conclusions from the previous tests should extend to this new variable. We show here that this is indeed the case.

Table 14 provides a preliminary look at the impact of sovereign defaults on unemployment. The table replicates the specifications of Table 7 using unemployment instead of real output growth as the dependent variable-that is, including the lagged dependent variable to control for unemployment persistence. As before, we find that whatever negative influence default may have on unemployment, it materializes before the actual default takes place. In particular, the increase in unemployment in the run-up to default (with the highest increase leading default by three quarters) reverts in the quarter of default. ${ }^{13}$

\footnotetext{
${ }^{13}$ Most of the findings reported here for output growth are also obtained for the case of the unempoyment rate. Results are available upon request.
} 


\section{Conclusions}

This paper delivers a simple and sobering message: contrary to what it is typically presumed, defaults have not been followed by output contractions. In fact, we find that the opposite seems to be the case: the default quarter coincides with the trough of the output contraction and marks the start of the economic recovery. This, however, does not appear to reflect a "benign" effect of defaults but rather the fact that the latter are typically associated with particularly deep recessions and, as a result, particularly steep recoveries.

This finding has important policy implications for debt management policies-and, indirectly, for debt sustainability - that should be clarified. It does not imply that policies that lead to default have no cost; on the contrary, the large GDP decline that typically precedes a default may reflect in part the anticipation of the default decision. Indeed, it could be argued that, if strategic defaults are costly, policymakers would only choose to default when these costs are inevitable or have already been paid, hence the absence of observed costs documented in this paper. $^{14}$

However, the findings that these costs are largely paid before the default decision is made also suggests that policymakers' effort to further postpone a default that has been widely anticipated and priced in by the market may be misguided. More generally, the argument bears the question about the optimal timing of default. If the default decision entails a tradeoff between the burden of servicing the debt (which grows as the crisis deepens and rollover costs mount), and the additional cost of default (which declines as the crisis takes its toll), is the absence of observed costs documented here an indication that defaults are often deferred for too long? Are politicians willing to have the economy make a suboptimal effort to avoid a default that has larger political than welfare costs? ${ }^{15}$ Is this agency problem and the associated political cost the ultimate reason why countries honor their debts? Certainly fruitful questions for future research.

\footnotetext{
${ }^{14}$ The finding that virtually all defaults appear to be driven by an adverse external context rather than by opportunistic behavior in times of bonanza is consistent with this view.

${ }^{15}$ Borensztein and Panizza (2005a) discuss this hypothesis.
} 


\section{References}

Ades, A. et al. 2000. "Introducing GS-ESS: A New Framework for Assessing Fair Value in Emerging Markets Hard-Currency Debt.” New York, United States: Goldman Sachs. www.goldmansachs.com.

Barro, R.J., and J-W. Lee. 2000. "Internatinal Data on Educational Attainment: Updates and Implications.” CID Working Paper 42. Cambridge, United States: Harvard University, Center for International Development.

Beers, D. 2004. “Sovereign Defaults Set to Fall Again in 2005.” New York, United States: Standard and Poors.

Beaudry, P., and G. Koop. 1993. “Do Recessions Permanently Change Output?” Journal of Monetary Economics 31: 149-63.

Blustein, P. 2005. And the Money Kept Rolling In (and Out). New York, United States: Public Affairs.

Bodman, P.M., and M. Crosby. 1998. “The Australian Business Cycle: Joe Palooka or Dead Cat Bounce.” Department of Economics Working Paper 586. Melbourne, Australia: University of Melbourne.

Borensztein, E., and U. Panizza. 2005a. “The Cost of Default.” Washington, DC, United States: Inter-American Development Bank, Research Department. Mimeographed document.

Borensztein, E. and U. Panizza (2005b), “Do Sovereign Defaults Hurt Exporters?” Washington, DC, United States: Inter-American Development Bank, Research Department. Mimeographed document.

Caprio, G., and D. Klingebiel. 2003. “Episodes of Systemic and Borderline Financial Crises.” Washington, DC, United States: World Bank. http://econ.worldbank.org/

Eaton, J., and M. Gersovitz. 1981. "Debt with Potential Repudiation: Theoretical and Empirical Analysis.” Review of Economic Studies 48(2): 289-309.

Global Development Finance. 2003. Analysis and Statistical Appendix. Washington, DC, United States: World Bank.

Hamilton, J.D. 1989. “A New Approach to the Economic Analysis of Nonstationary Time Series and the Business Cycle.” Econometrica 57: 357-84.

International Financial Statistics. Washington, DC, United States: International Monetary Fund. wWw.imf.org. 
Jansen, D., and W. Oh. 1999. "Modeling Nonlinearity of Business Cycles: Choosing between the CDR and STAR Models.” Review of Economics and Statistics 81: 344-349.

Kaminsky, G., and C. Reinhart. 1999. “The Twin Crises: The Causes of Banking and Balanceof-Payments Problems.” American Economic Review 89(3): 473-500.

Levy Yeyati, E. 2006. “Optimal Debt? On the Insurance Value of International Debt Flows to Developing Countries.” Washington, DC, United States: Inter-American Development Bank, Research Department. Mimeographed document.

Martínez, J.V., and G. Sandleris. 2004. "Is it Punishment? Sovereign Defaults and the Declines in Trade.” New York, United States: Columbia University. Mimeographed document.

Neftci, S.N. 2001. “Are Economic Time Series Asymmetric over the Business Cycle?” Journal of Political Economy 92: 307-28.

Ozler, S. 1993. “Have Commercial Banks Ignored History?” American Economic Review 83(3): 608-20.

Pernice, S., and F. Sturzenegger. 2004. "Culture and Social Resistance to Reform: A Theory about the Endogeneity of Public Beliefs with an Application to the Case of Argentina.” CEMA Working Paper 275. Buenos Aires, Argentina: CEMA University.

Rose, A. 2002. “One Reason Countries Pay Their Debts: Renegotiation and International Trade.” NBER Working Paper 8853. Cambridge, United States: National Bureau of Economic Research.

Sturzenegger, F. 2004. “Toolkit for the Analysis of Debt Problems.” Journal of Restructuring Finance 1(1): 201-203. 
Figures and Tables

Figure 1:

Default and GDP Growth. Argentina

(GDP seasonally adjusted)

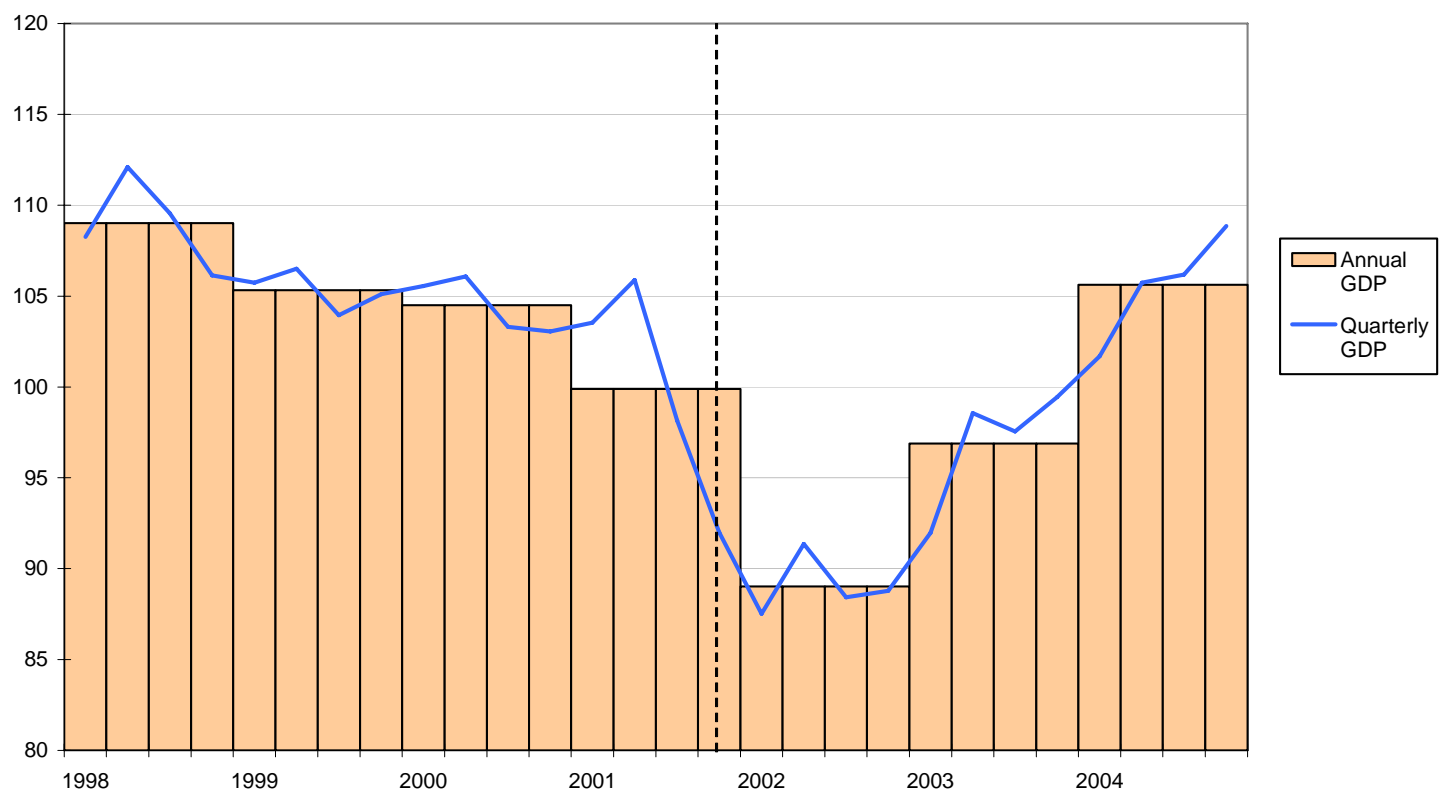

Figure 1:

Default and GDP Growth. Ecuador

(GDP seasonally adjusted)

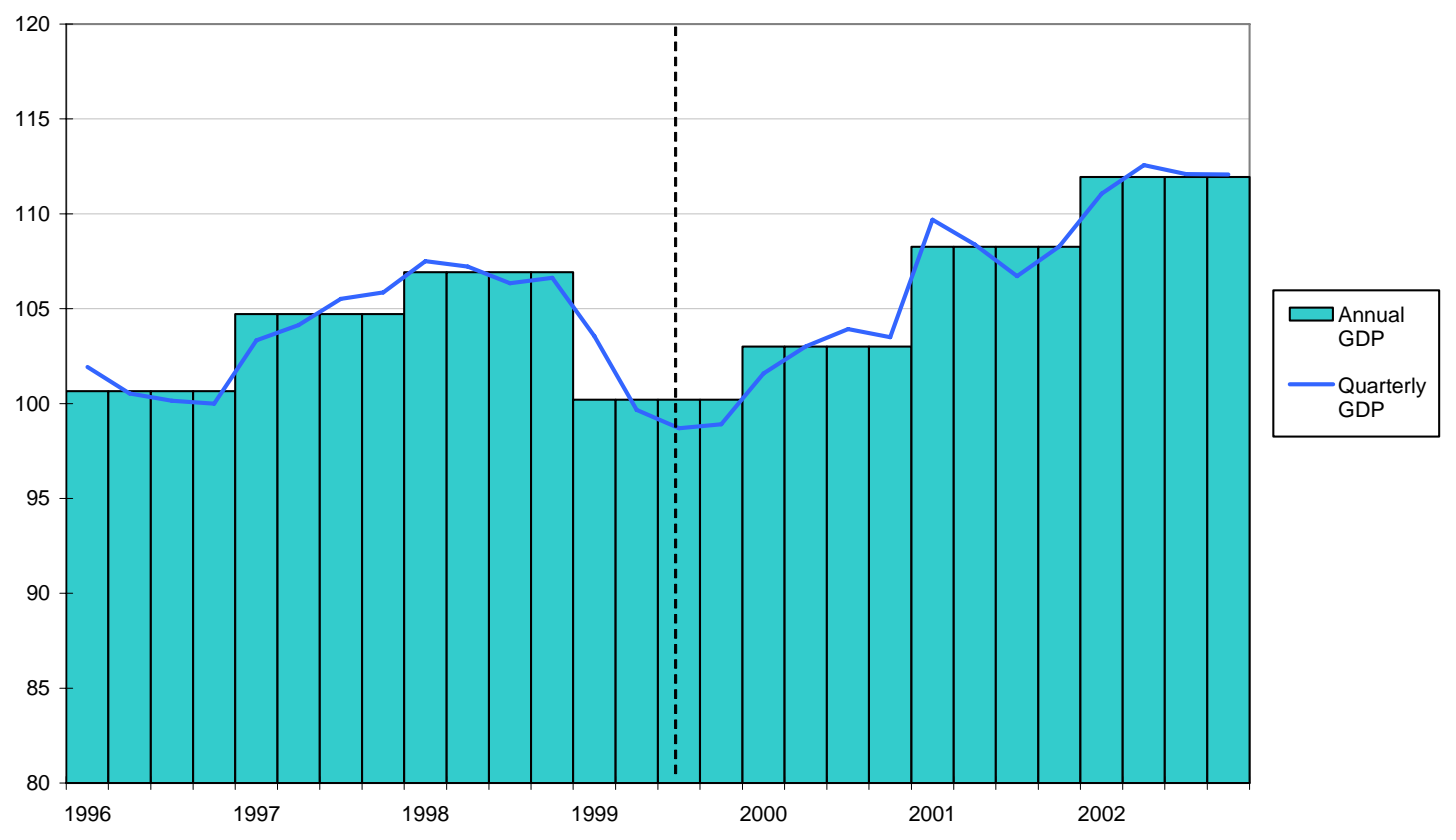


Figure 1:

Default and GDP Growth. Indonesia

(GDP seasonally adjusted)

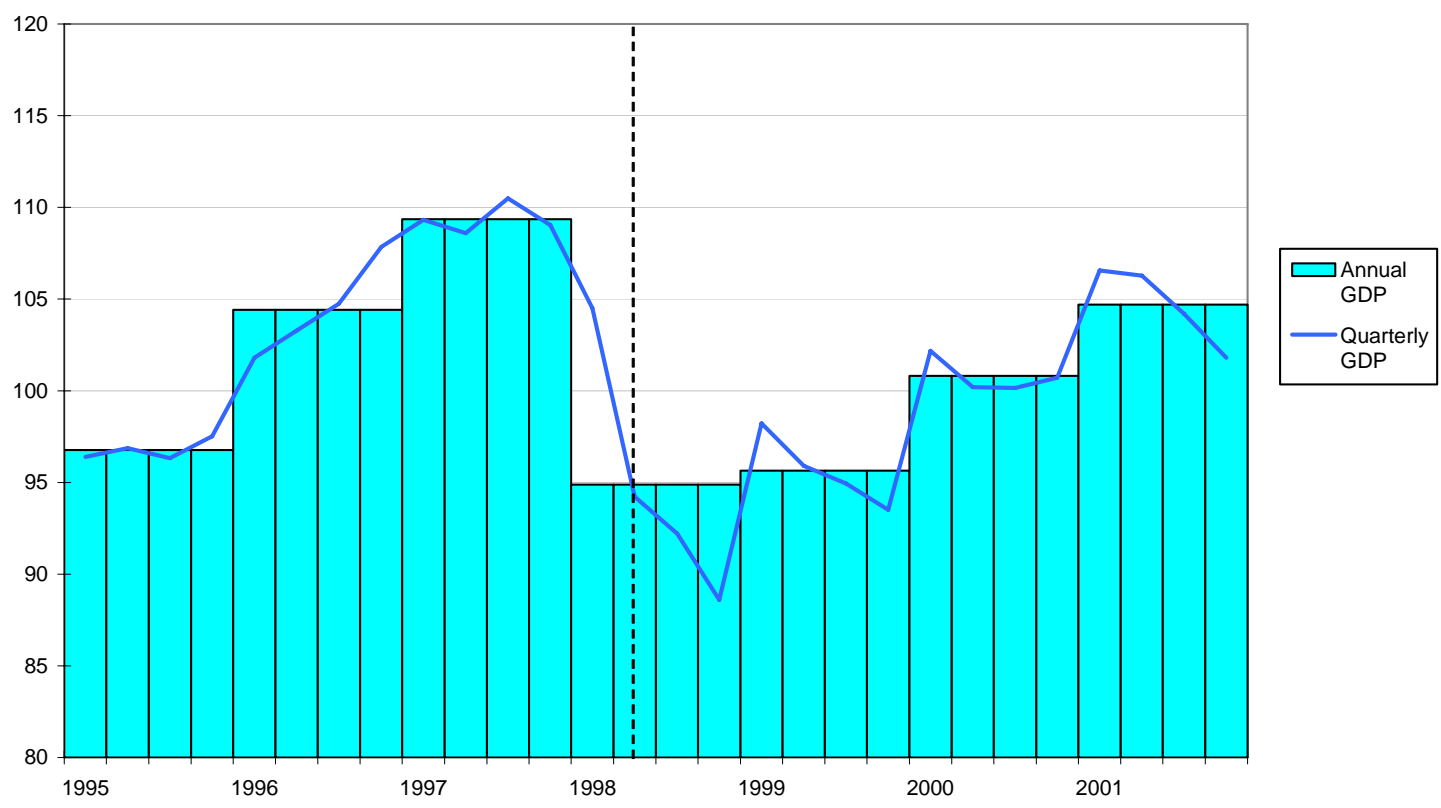

Figure 1:

Default and GDP Growth. Russia

(GDP seasonally adjusted)

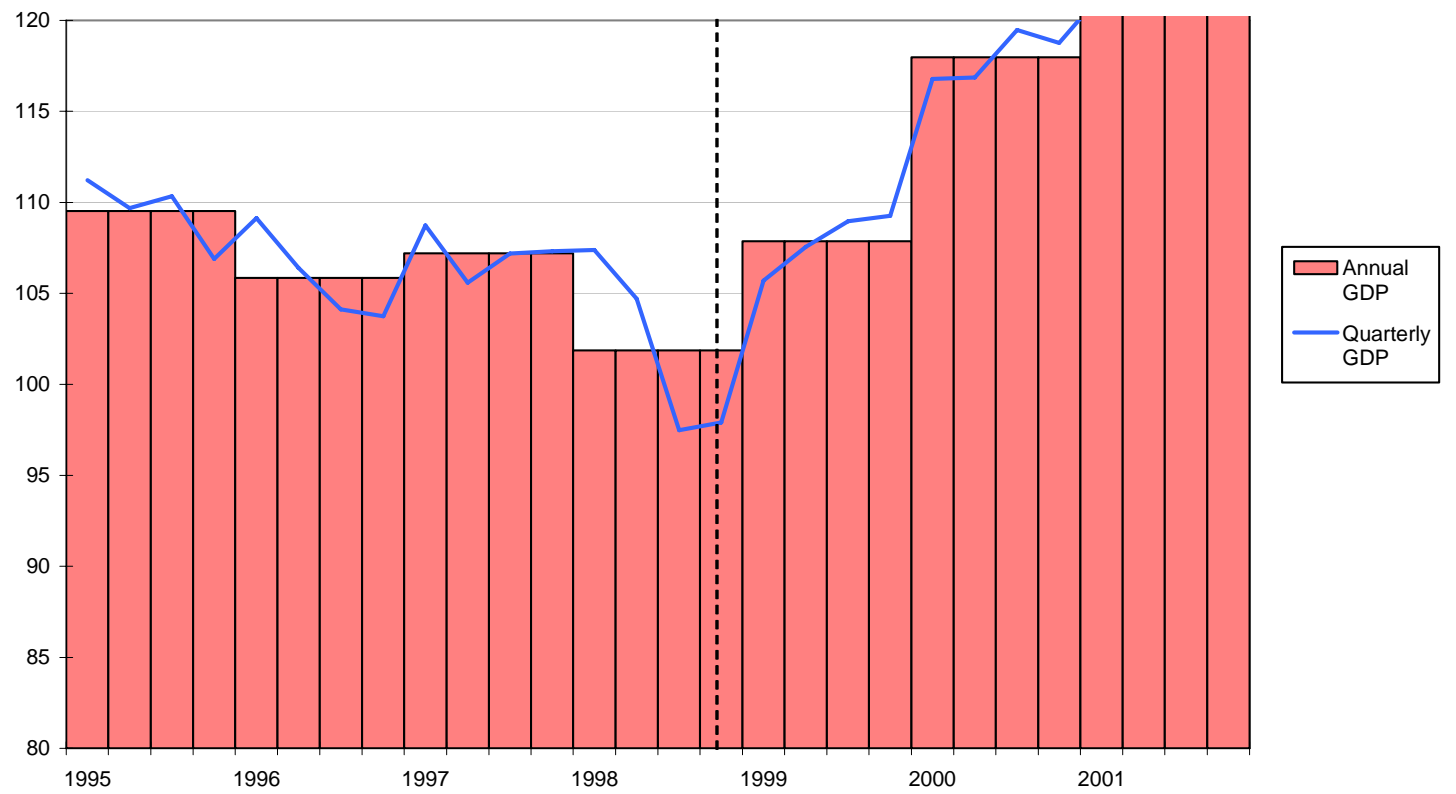


Figure 1:

Default and GDP Growth. Ukraine

(GDP seasonally adjusted)

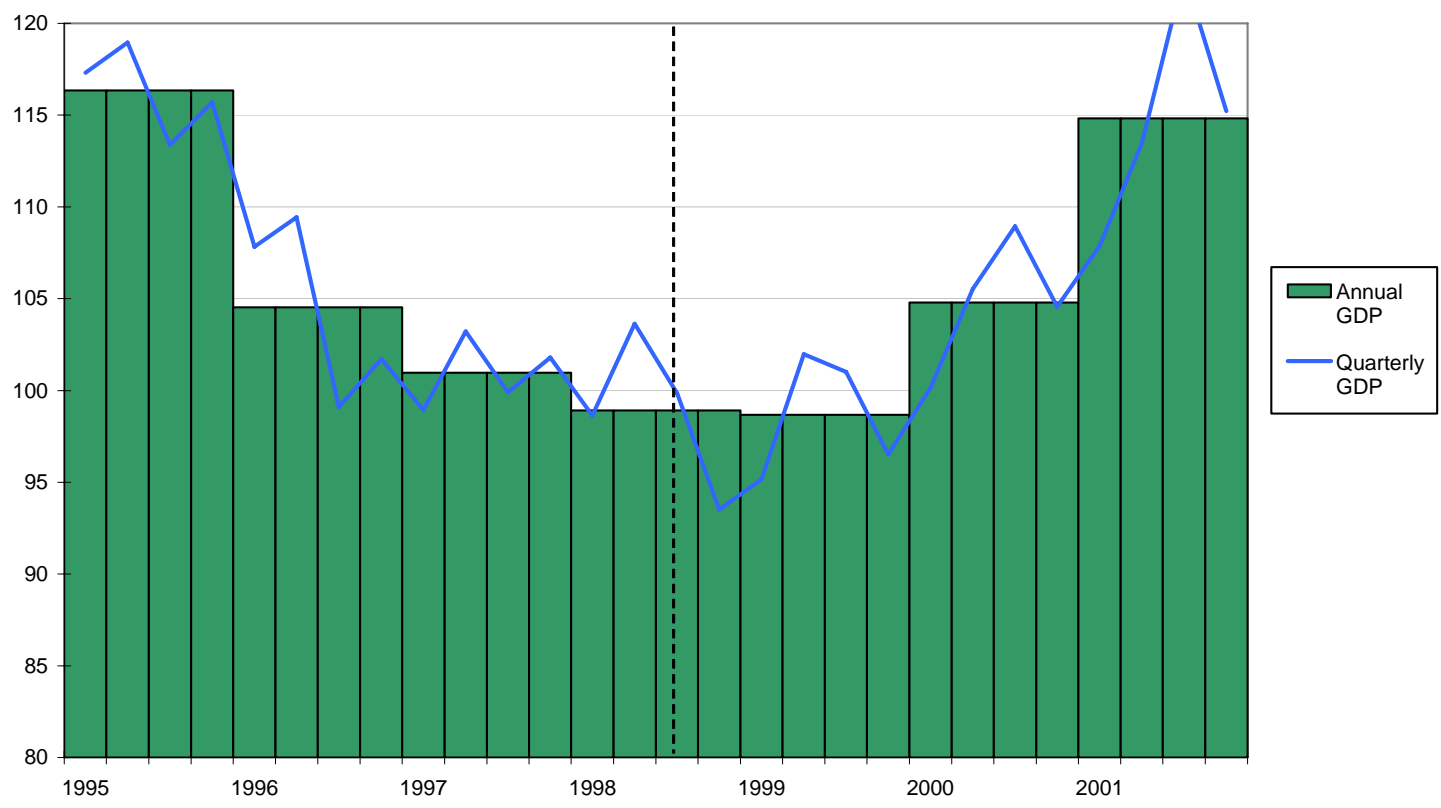

Figure 1:

Default and GDP Growth. Uruguay

(GDP seasonally adjusted)

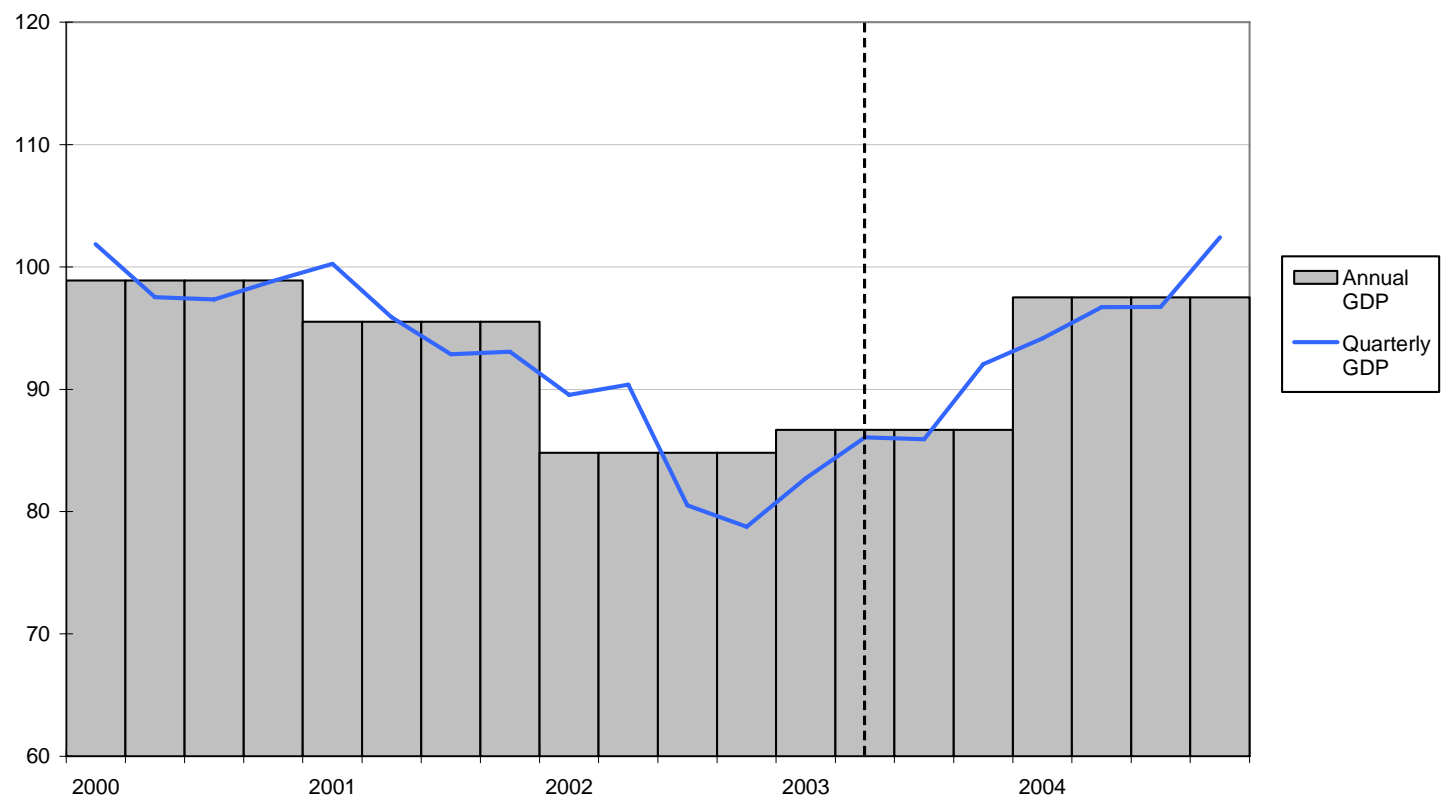


Figure 1:

Default and GDP Growth. Pakistan

(GDP seasonally adjusted)

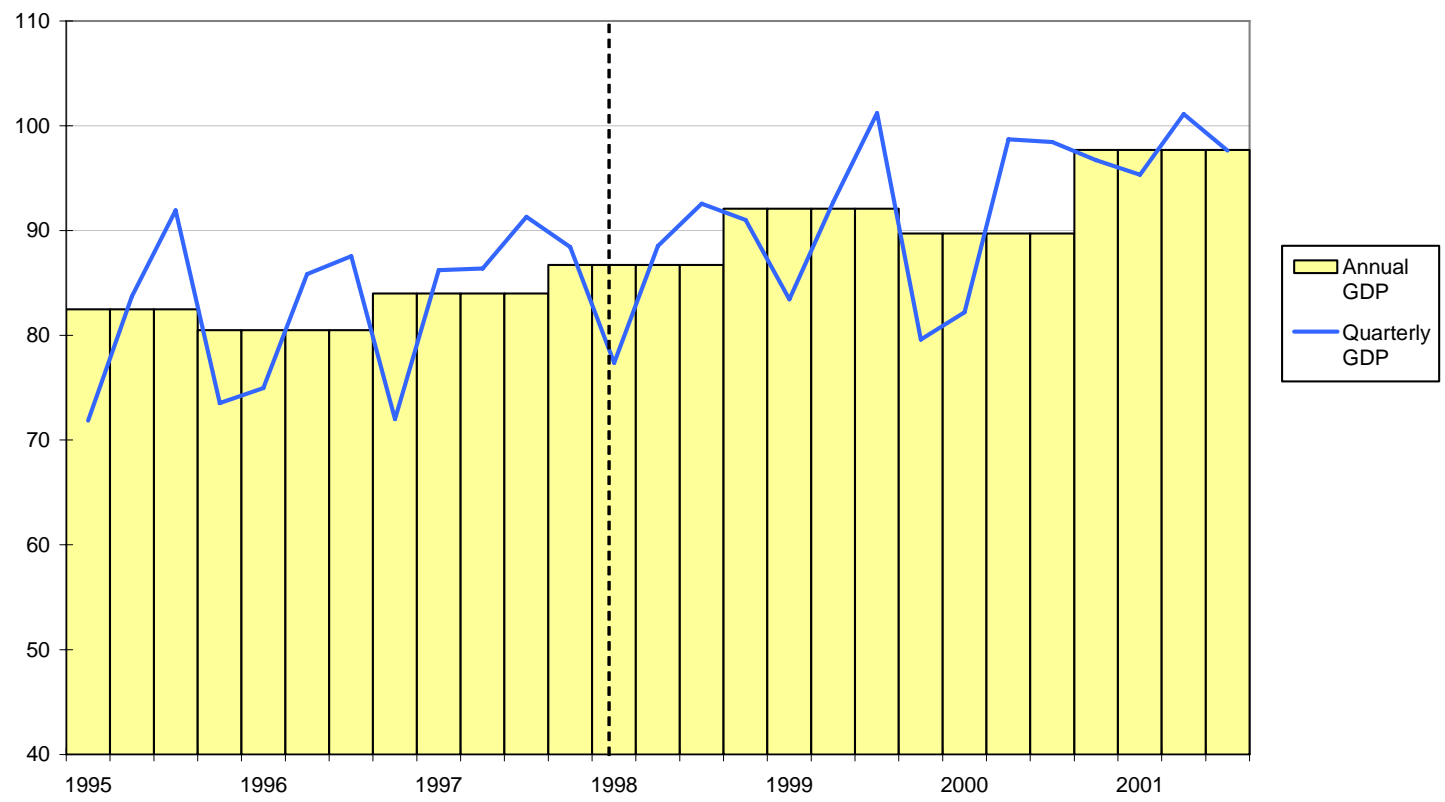

Figure 2:

GDP around Default

(GDP seasonally adjusted)

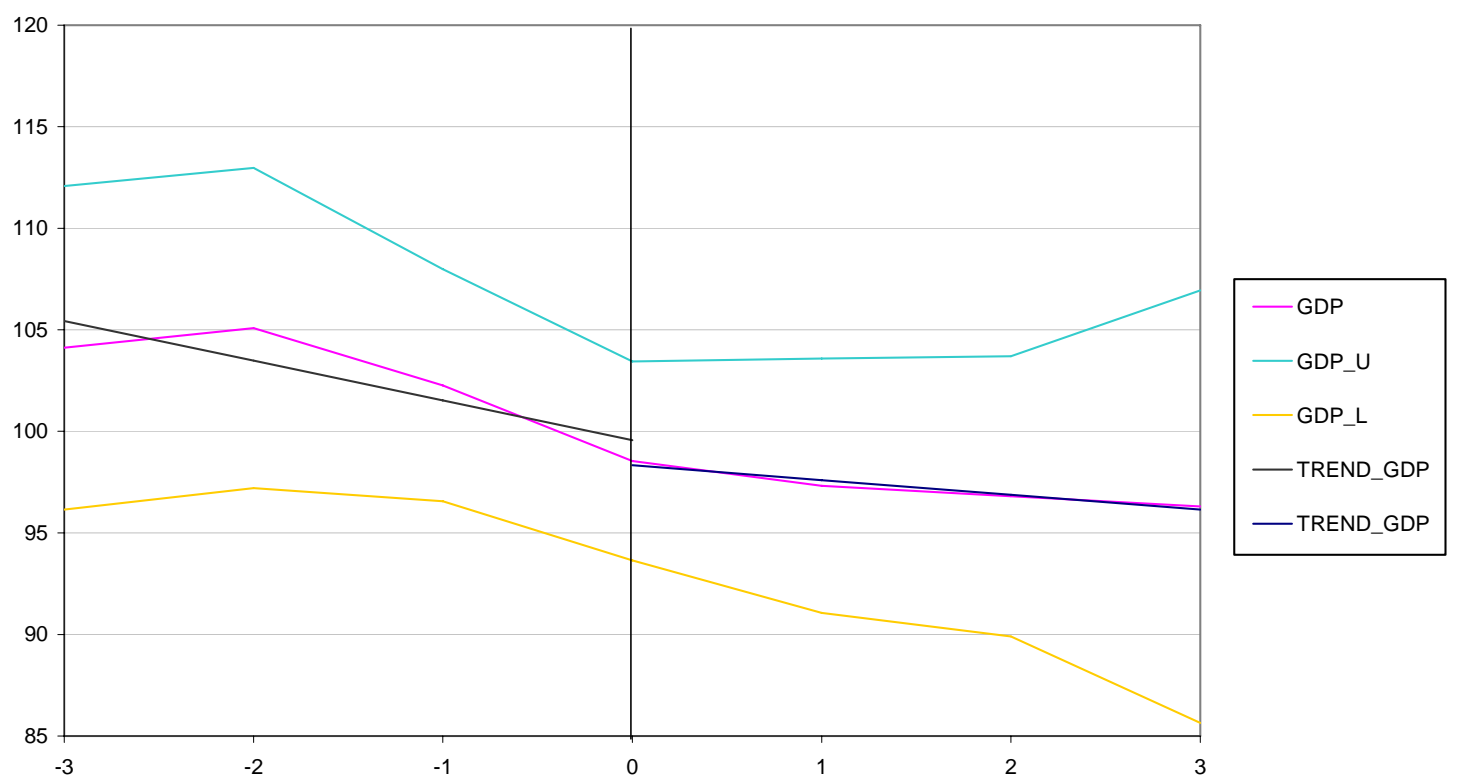


Figure 2:

GDP around Default

(GDP seasonally adjusted)

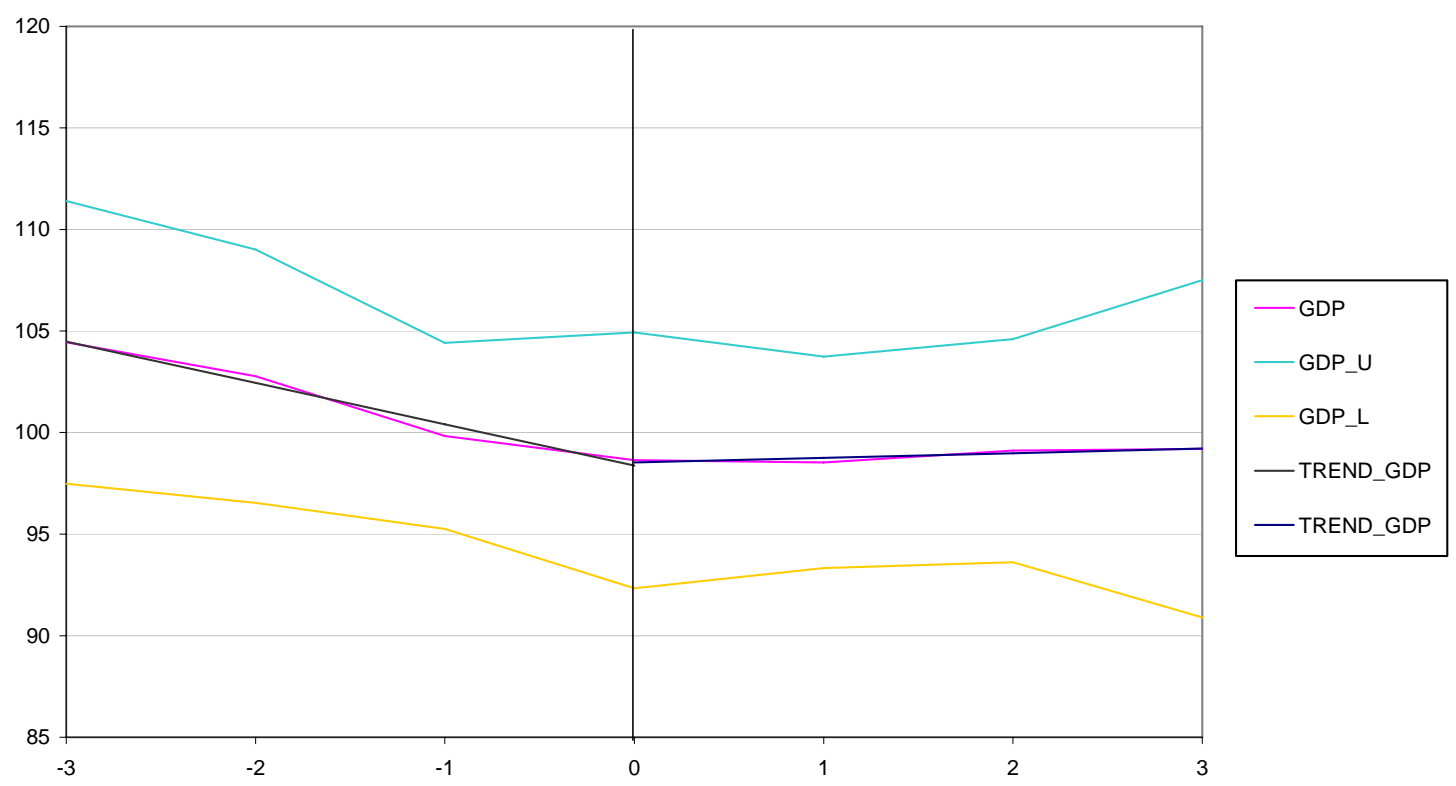

Figure 2:

GDP around Default

(GDP seasonally adjusted)

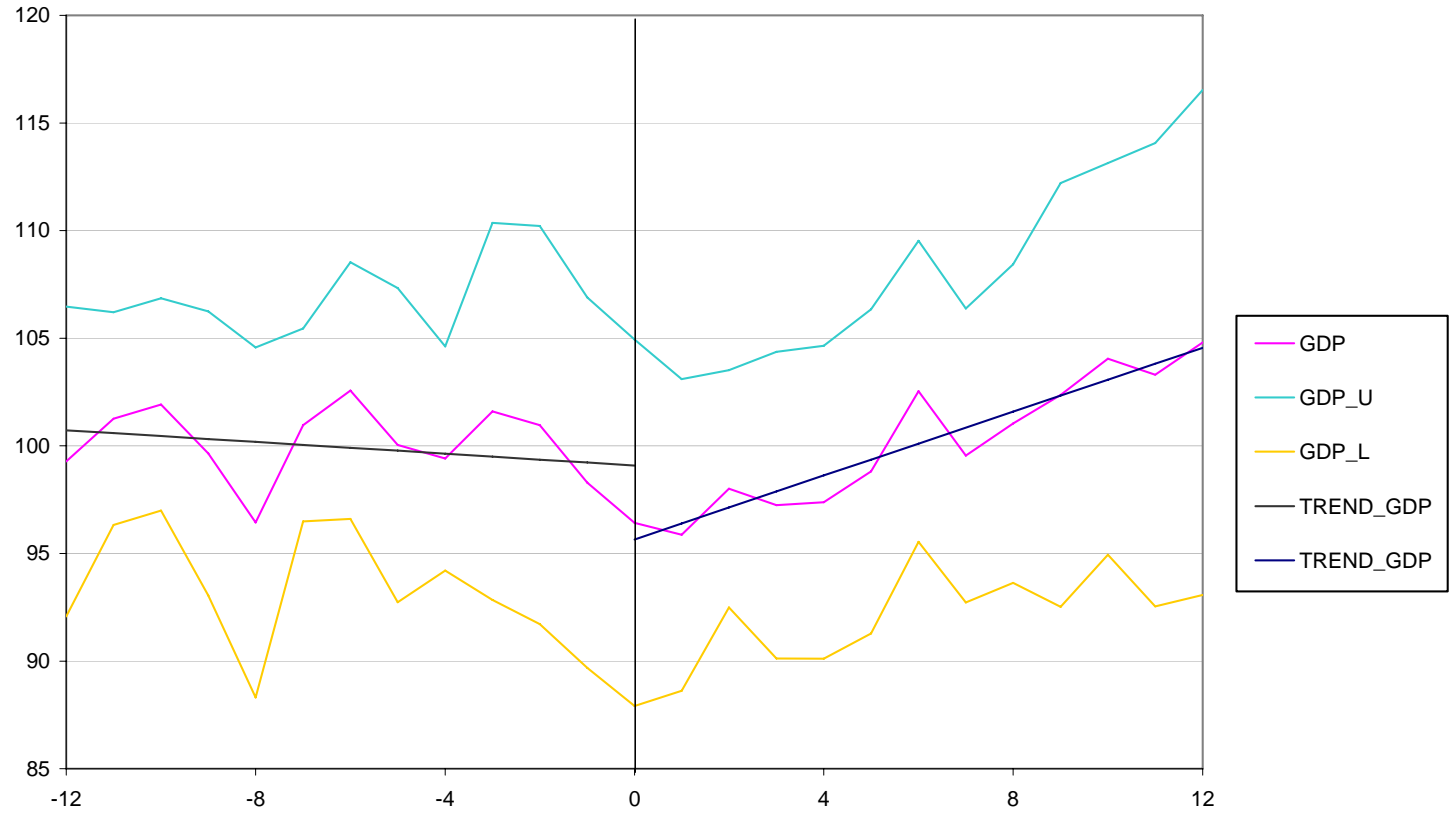


Figure 3:

Cumulative Output Growth before and after Default (growth of GDP seasonally adjusted)

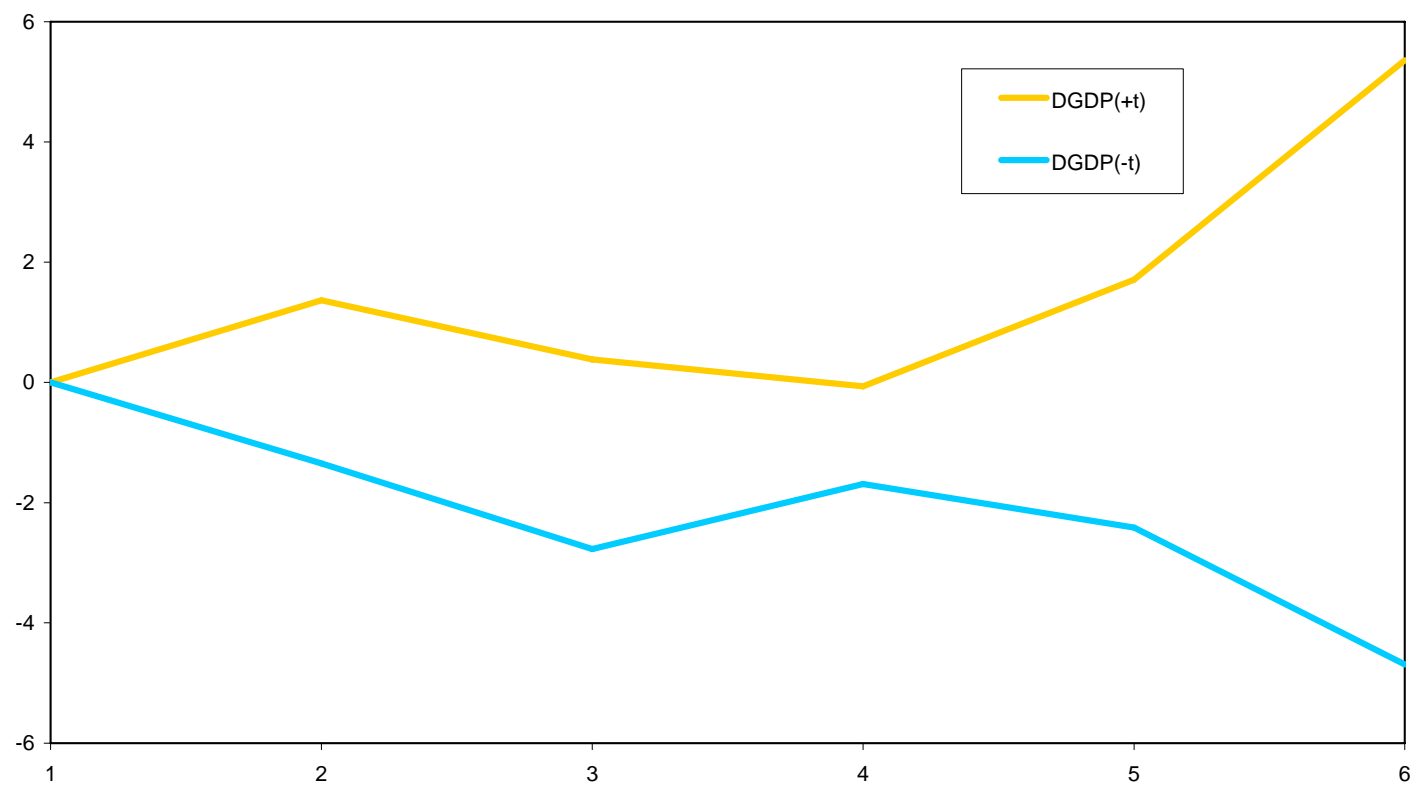

Figure 4:

GDP around Default

(HP filtered GDP)

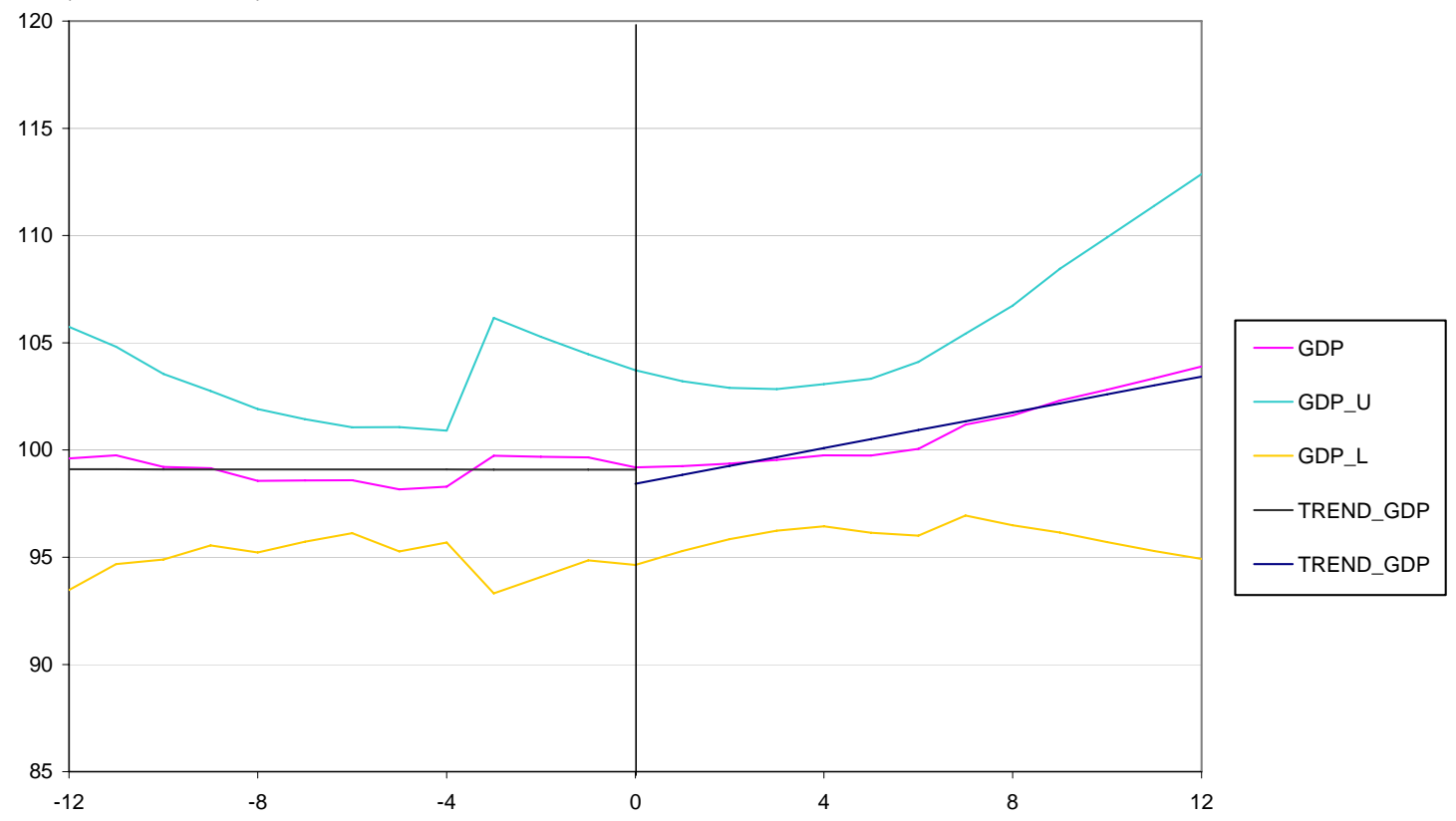


Table 1. Summary Statistics

A. Yearly Variables

\begin{tabular}{|l|ccccc|}
\hline Variable & Obs & Mean & Std. Dev. & Min & Max \\
\hline growth & 482 & 1.675 & 4.877 & -14.568 & 11.190 \\
invgdp & 460 & 1.773 & 0.725 & 0.329 & 4.215 \\
pop growth & 523 & 1.540 & 1.019 & -3.248 & 3.390 \\
sec & 415 & 21.889 & 10.841 & 3.800 & 52.400 \\
pop level & 523 & 45.085 & 43.462 & 3.060 & 212.000 \\
gov & 460 & 0.035 & 0.095 & -0.256 & 0.700 \\
civil & 495 & 3.741 & 1.228 & 1.000 & 7.000 \\
tt & 474 & -0.010 & 0.158 & -2.080 & 1.067 \\
openness & 484 & 0.299 & 0.168 & 0.052 & 1.146 \\
bank2av1 & 533 & 0.167 & 0.373 & 0 & 1 \\
def & 533 & 0.043 & 0.203 & 0 & 1 \\
\hline
\end{tabular}

\section{B. Quarterly Variables}

\begin{tabular}{|l|ccccc|}
\hline \multicolumn{1}{|c|}{ Variable } & Obs & Mean & Std. Dev. & Min & Max \\
\hline $\begin{array}{l}\text { growth } \\
\begin{array}{l}\text { external } \\
\text { mkt } \\
\text { pressure }\end{array}\end{array}$ & 2,326 & 0.723791 & 5.558707 & -27.3833 & 29.99361 \\
& 1,298 & 90.78833 & 22.97053 & 13.93941 & 200.5199 \\
& & & & & \\
\end{tabular}


Table 2: Default Episodes Included in the Sample

\begin{tabular}{|ccc|c|}
\hline Country & Year & Quarter & Default \\
\hline \hline Argentina & 1982 & 1 & Default on external bank loans \\
& 2001 & 4 & Default on external bonds/Default on external bank \\
Chile & 1983 & 1 & loans \\
Dominican & 1982 & 4 & Default on external bank loans \\
Republic & 1999 & 2 & Default on external bank loans \\
Ecuador & 1999 & 3 & Default on domestic bonds \\
Indonesia & 1998 & 2 & Default on external bonds \\
Mexico & 1982 & 3 & Default on external bank loans \\
Nigeria & 1983 & 3 & Default on external bank loans \\
& 1986 & 3 & Default on external bank loans \\
Pakistan & 1997 & 3 & Default on external bonds \\
& 1998 & 2 & Paris club default \\
Peru & 1980 & 1 & Default on external bank loans \\
& 1983 & 1 & Default on external bank loans \\
Philippines & 1983 & 4 & Default on external bank loans \\
& 1991 & 4 & Default on external bank loans \\
Russia & 1998 & 3 & Default on external bank loans \\
& 1998 & 4 & Default on domestic bonds \\
South & 1985 & 3 & Default on external bonds \\
Africa & 1989 & 4 & Default on external bank loans \\
Ukraine & 1998 & 3 & Default on external bank loans \\
& 1990 & 1 & Default on domestic bonds/Default on external \\
Uruguay & 2003 & 2 & bonds/Default on domestic bonds \\
& & Default on external bank loans \\
& & Default on external bonds \\
\hline
\end{tabular}


Table 3. Growth regressions (yearly data)

\begin{tabular}{|c|c|c|c|c|c|c|c|c|c|c|c|}
\hline \multirow{4}{*}{$\begin{array}{l}\text { Independent } \\
\text { variables } \\
\text { invgdp }\end{array}$} & \multicolumn{11}{|c|}{ Dependent variable: yearly GDP growth } \\
\hline & \multicolumn{7}{|c|}{ Full sample } & \multicolumn{4}{|c|}{ Emerging economies } \\
\hline & $\operatorname{Reg} 1$ & $\operatorname{Reg} 2$ & $\operatorname{Reg} 3$ & $\operatorname{Reg} 4$ & $\operatorname{Reg} 5$ & Reg 6 & $\operatorname{Reg} 7^{1}$ & $\operatorname{Reg} 8$ & $\operatorname{Reg} 9$ & Reg 10 & $\operatorname{Reg} 11^{2}$ \\
\hline & $\begin{array}{c}1.834 \\
(7.18)^{* * *}\end{array}$ & $\begin{array}{c}1.784 \\
(6.99)^{* * *}\end{array}$ & $\begin{array}{c}1.780 \\
(6.95)^{* * *}\end{array}$ & & & & & & & & \\
\hline pop growth & $\begin{array}{c}-0.452 \\
(3.10)^{* * *}\end{array}$ & $\begin{array}{c}-0.444 \\
(3.00)^{* * *}\end{array}$ & $\begin{array}{c}-0.452 \\
(3.07)^{* * *}\end{array}$ & & & & & & & & \\
\hline sec & $\begin{array}{l}-0.015 \\
(0.99)\end{array}$ & $\begin{array}{r}-0.018 \\
(1.22)\end{array}$ & $\begin{array}{r}-0.022 \\
(1.47)\end{array}$ & & & & & & & & \\
\hline pop level & $\begin{array}{l}0.003 \\
(0.72)\end{array}$ & $\begin{array}{l}0.003 \\
(0.78)\end{array}$ & $\begin{array}{l}0.003 \\
(0.89)\end{array}$ & & & & & & & & \\
\hline gov & $\begin{array}{c}3.161 \\
(3.16)^{* * *}\end{array}$ & $\begin{array}{c}3.201 \\
(3.20)^{* * *}\end{array}$ & $\begin{array}{c}3.086 \\
(3.08)^{* * *}\end{array}$ & & & & & & & & \\
\hline civil & $\begin{array}{l}0.027 \\
(0.24)\end{array}$ & $\begin{array}{l}0.028 \\
(0.25)\end{array}$ & $\begin{array}{l}0.029 \\
(0.27)\end{array}$ & & & & & & & & \\
\hline$\Delta \mathrm{tt}$ & -0.331 & -0.214 & 0.911 & & & & & & & & \\
\hline & $(0.28)$ & $(0.18)$ & $(1.93)^{*}$ & & & & & & & & \\
\hline openness & $\begin{array}{c}5.809 \\
(3.75) * * *\end{array}$ & $\begin{array}{c}5.993 \\
(3.87)^{* * *}\end{array}$ & $\begin{array}{c}6.797 \\
(4.45) * * *\end{array}$ & & & & & & & & \\
\hline bank2av1 & $\begin{array}{c}-0.979 \\
(4.04)^{* * *}\end{array}$ & $\begin{array}{c}-0.920 \\
(3.81)^{* * *}\end{array}$ & $\begin{array}{c}-0.948 \\
(3.95) * * *\end{array}$ & & & & & & & & \\
\hline $\operatorname{def}(T-1)$ & & $\begin{array}{c}-2.638 \\
(3.76)^{* * *}\end{array}$ & $\begin{array}{c}-2.618 \\
(3.75)^{* * *}\end{array}$ & & $\begin{array}{c}-3.013 \\
(5.34)^{* * *}\end{array}$ & $\begin{array}{c}-3.001 \\
(5.31)^{* * *}\end{array}$ & & $\begin{array}{c}-3.297 \\
(2.43)^{* *}\end{array}$ & $\begin{array}{c}-3.410 \\
(2.54)^{* *}\end{array}$ & & \\
\hline Def & -3.010 & -3.207 & & -3.549 & -3.824 & & -3.343 & -3.715 & & -3.051 & -3.505 \\
\hline $\operatorname{def}(T+1)$ & $(3.45)^{* * *}$ & $\begin{array}{c}(3.67)^{* * *} \\
-0.552 \\
(0.89)\end{array}$ & $\begin{array}{c}-0.458 \\
(0.73)\end{array}$ & $(6.56)^{* * *}$ & $\begin{array}{c}(7.08) * * * \\
-2.212 \\
(3.74)^{* * *}\end{array}$ & $\begin{array}{c}-2.188 \\
(3.64)^{* * *}\end{array}$ & $(3.98)^{* * *}$ & $\begin{array}{c}(3.56) * * * \\
-2.352 \\
(2.05)^{* *}\end{array}$ & $\begin{array}{c}-2.348 \\
(2.01)^{* *}\end{array}$ & $(3.15)^{* * *}$ & $(2.11)^{* *}$ \\
\hline Constant & $\begin{array}{c}-2.179 \\
(2.69) * * *\end{array}$ & $\begin{array}{c}-2.061 \\
(2.53)^{* *}\end{array}$ & $\begin{array}{c}-2.236 \\
(2.74)^{* * *}\end{array}$ & $\begin{array}{c}1.604 \\
(26.04)^{* * *}\end{array}$ & $\begin{array}{c}1.689 \\
(27.11)^{* * *}\end{array}$ & $\begin{array}{c}1.697 \\
(27.34)^{* * *}\end{array}$ & $\begin{array}{c}1.724 \\
(21.14)^{* * *}\end{array}$ & $\begin{array}{c}2.080 \\
(8.90)^{* * *}\end{array}$ & $\begin{array}{c}2.118 \\
(9.20)^{* * *}\end{array}$ & $\begin{array}{c}1.814 \\
(8.41)^{* * *}\end{array}$ & $\begin{array}{c}1.828 \\
(7.37)^{* * *}\end{array}$ \\
\hline Observations & 2,153 & 2,153 & 2,114 & 4,841 & 4,839 & 4,763 & 2,153 & 454 & 433 & 482 & 287 \\
\hline Countries & 89 & 89 & 89 & 181 & 181 & 181 & 89 & 28 & 28 & 28 & 14 \\
\hline R-squared & 0.10 & 0.11 & 0.10 & 0.01 & 0.02 & 0.01 & 0.10 & 0.05 & 0.03 & 0.02 & 0.03 \\
\hline
\end{tabular}

Notes: All regressions include country fixed effects. Robust t statistics in parentheses, * significant at $10 \%$; ** significant at $5 \%$; *** significant at $1 \%$

${ }^{1}$ Same sample as in column (1). ${ }^{2}$ Sample used in the quarterly regressions. 
Table 4. Quarterly Data, Baseline Model

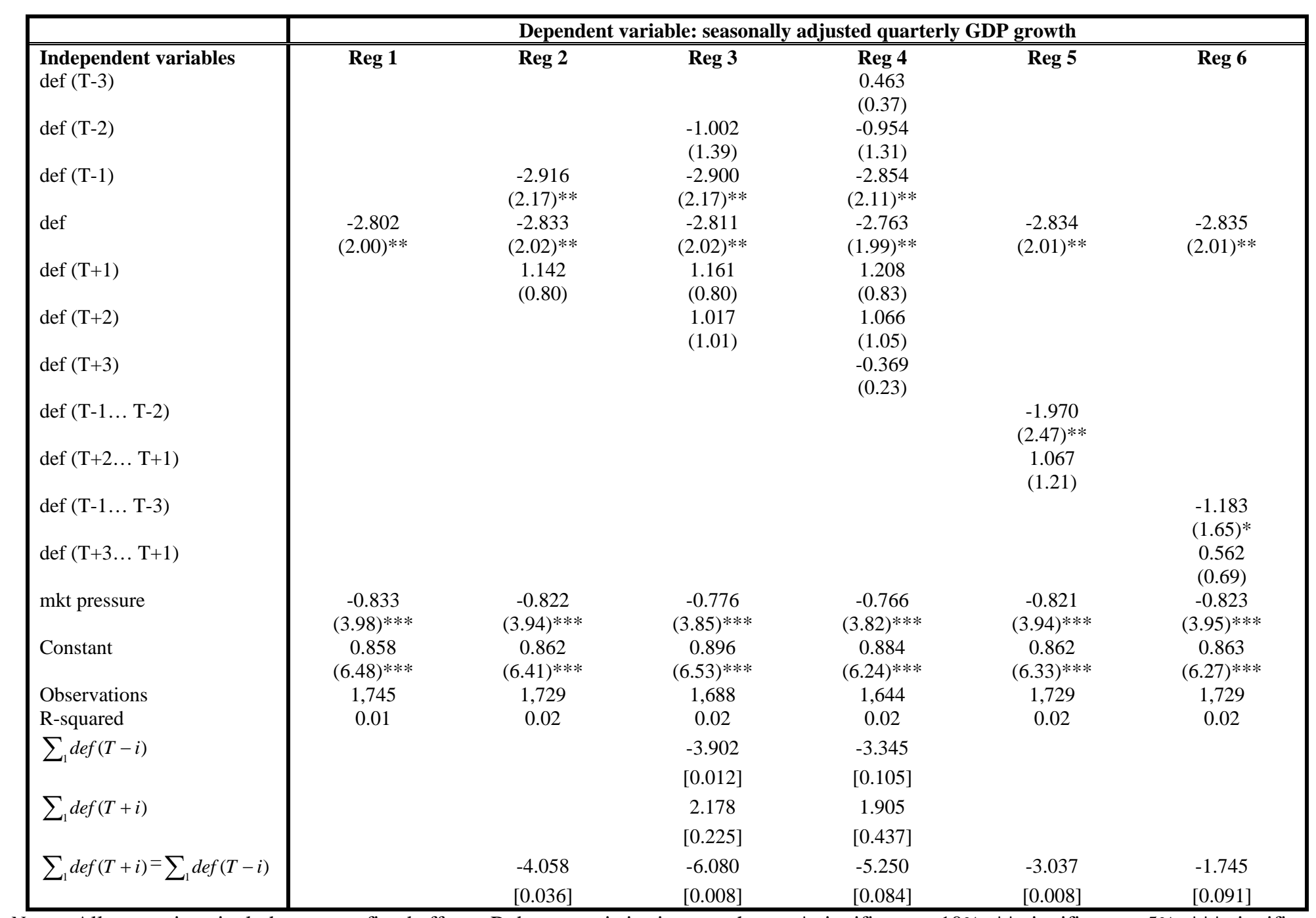

Notes: All regressions include country fixed effects. Robust t statistics in parentheses, * significant at 10\%; ** significant at 5\%; *** significant at 1\%. P-value of F-tests in brackets. 
Table 5 Robustness I. Controlling for Lagged Growth

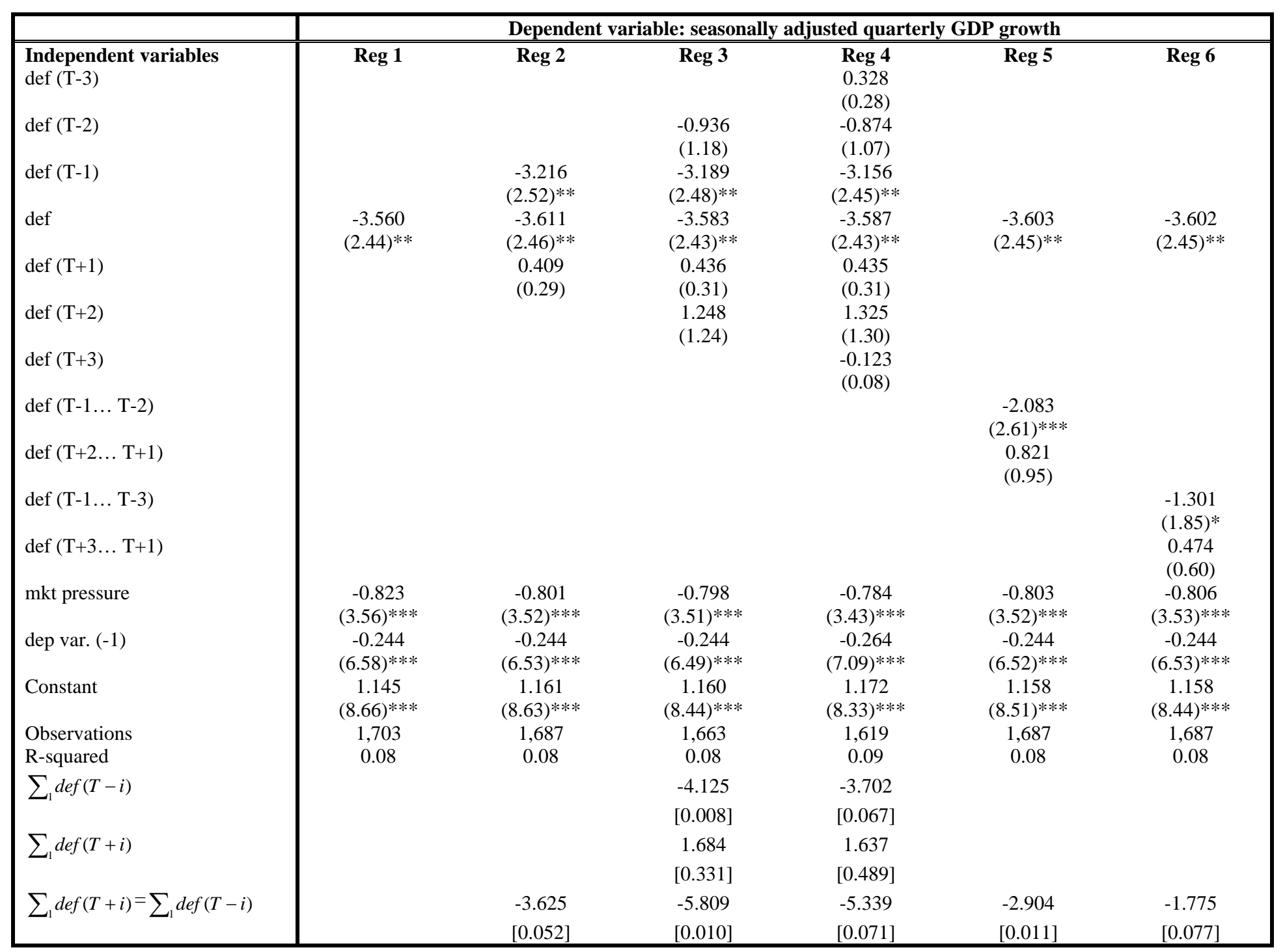

Notes: All regressions include country fixed effects. Robust t statistics in parentheses, * significant at $10 \%$; ** significant at $5 \%$; $* * *$ significant at $1 \%$. P-value of F-tests in brackets. 
Table 6. Robustness II. Controlling for Country-Year Effects

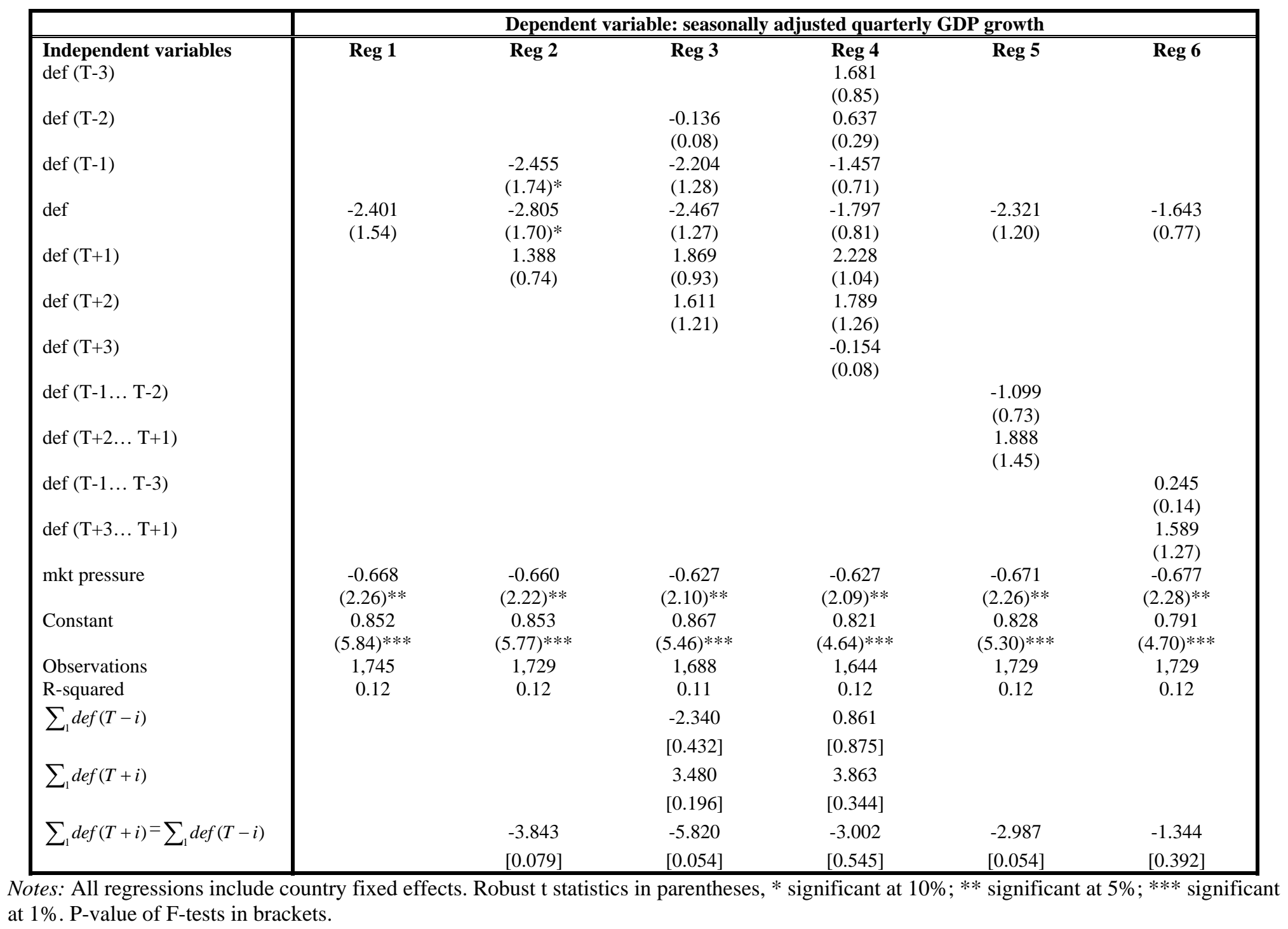


Table 7. Robustness III. Restricting the Estimation to a 3+3 Years Window

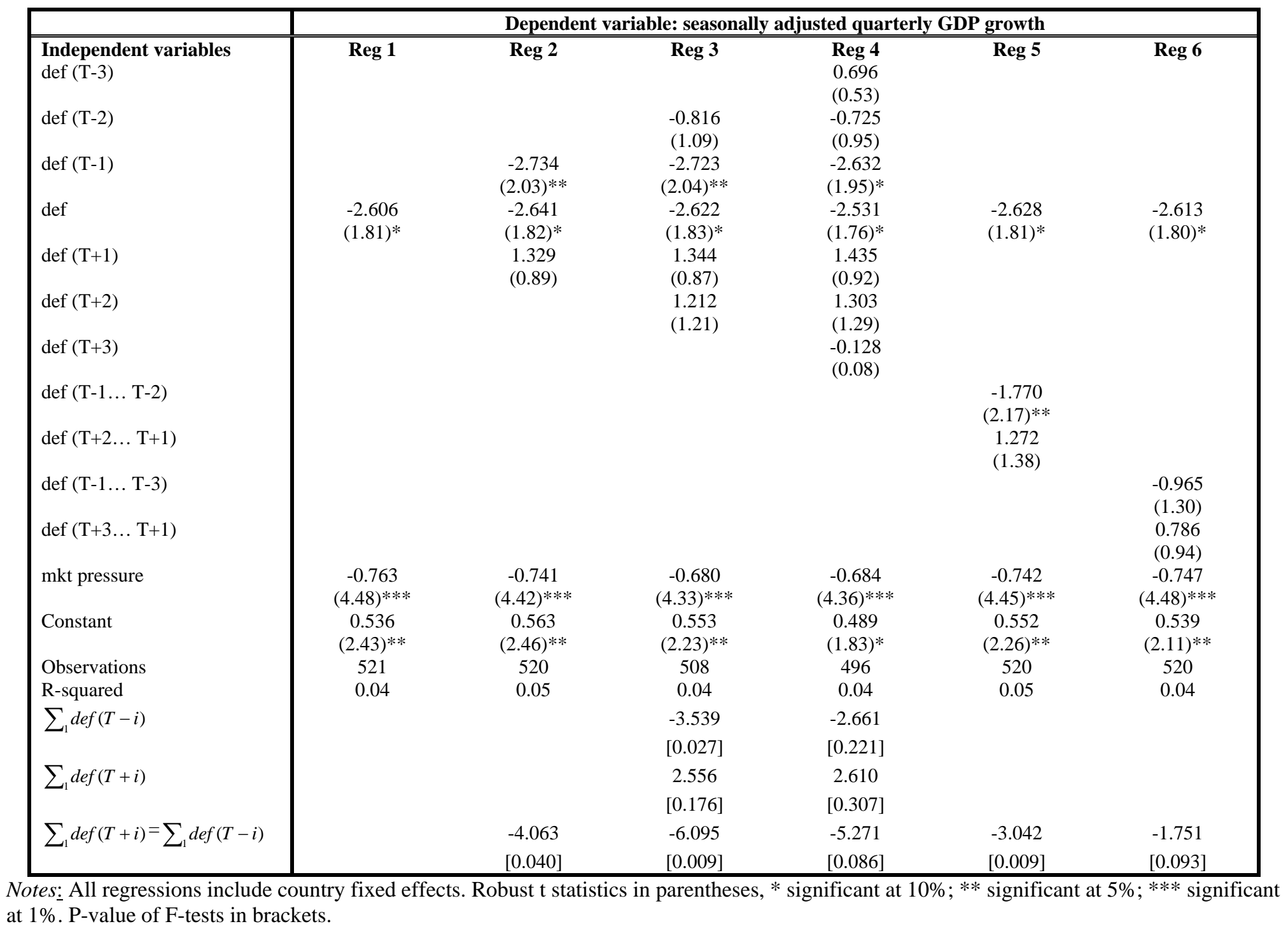


Table 8. Robustness IV. Dropping One Country at a Time

\begin{tabular}{|c|c|c|c|c|c|c|}
\hline \multirow[t]{2}{*}{ Dropping } & \multicolumn{2}{|c|}{ Contemporaneous effect } & \multicolumn{2}{|c|}{$\mathbf{T}+\mathbf{1}$} & \multicolumn{2}{|c|}{ T-1 } \\
\hline & Coefficient & |t-statistics & Coefficient & $\mid \mathrm{t}$-statistics $\mid$ & Coefficient & $\mid t$-statistics $\mid$ \\
\hline & -2.37 & 2.18 & -1.02 & 0.75 & -3.09 & 2.13 \\
\hline Argentina & -2.31 & 2.10 & -0.34 & 0.23 & -2.81 & 1.79 \\
\hline Chile & -2.71 & 2.64 & -1.22 & 0.83 & -2.64 & 1.83 \\
\hline Dominican Republic & -2.35 & 2.15 & -1.21 & 0.82 & -3.45 & 2.38 \\
\hline Ecuador & -2.37 & 2.16 & -1.02 & 0.68 & -2.98 & 1.98 \\
\hline Indonesia & -1.87 & 1.88 & -0.86 & 0.58 & -2.93 & 1.95 \\
\hline Mexico & -2.37 & 2.16 & -0.87 & 0.59 & -2.96 & 1.97 \\
\hline Nigeria & -2.01 & 1.78 & -0.27 & 0.19 & -3.53 & 2.67 \\
\hline Pakistan & -1.79 & 1.92 & -1.79 & 1.45 & -3.04 & 2.03 \\
\hline Peru & -2.55 & 2.23 & -1.11 & 0.72 & -2.17 & 1.57 \\
\hline Philippines & -2.03 & 1.93 & -1.49 & 1.07 & -2.80 & 1.88 \\
\hline Russia & -2.77 & 2.50 & -0.89 & 0.66 & -3.23 & 2.10 \\
\hline South Africa & -2.41 & 2.08 & -1.16 & 0.74 & -3.23 & 2.03 \\
\hline Ukraine & -2.30 & 2.10 & -0.75 & 0.51 & -3.52 & 2.47 \\
\hline Uruguay & -2.88 & 2.65 & -0.83 & 0.53 & -3.51 & 2.30 \\
\hline
\end{tabular}

Notes: Specification (2) of Table 4. 
Table 9. Cumulative Output Growth before and after Default

\begin{tabular}{|l|cccc|}
\hline Change in Growth & Obs & Mean & DGP(-T)-DGP(+T) & $\begin{array}{c}\text { p-value } \\
\text { DGP(-T)-DGP(+T)<0 }\end{array}$ \\
\hline DGDP(-2) & 14 & -1.35 & -2.71 & 0.0766 \\
DGDP(+2) & 14 & 1.36 & -3.15 & 0.0797 \\
DGDP(-3) & 14 & -2.77 & & \\
DGDP(+3) & 14 & 0.38 & -1.63 & 0.2804 \\
DGDP(-4) & 13 & -1.69 & -4.13 & 0.0997 \\
DGDP(+4) & 14 & -0.06 & & \\
DGDP(-5) & 12 & -2.41 & -10.04 & 0.0037 \\
DGDP(+5) & 14 & 1.71 & -4.69 & \\
DGDP(-6) & 12 & 5.36 & \\
DGDP(+6) & 13 &
\end{tabular}

Notes: The table reports and compares the average cumulative growth rate before and after the default event, for windows of increasing length. For a window of length $2 \mathrm{~T}+1$, we drop the default quarter $\mathrm{t}=0$, and compute DGDP(-s) $=\left[\mathrm{GDP}_{-1} / \mathrm{GDP}_{-\mathrm{s}}\right]-1$, and $\mathrm{DGDP}(+\mathrm{s})=\left[\mathrm{GDP}_{+\mathrm{s}} / \mathrm{GDP}_{+1}\right]-1$. 
Table 10. Maximum Depth of the Recession and Default

\begin{tabular}{|c|c|c|c|c|c|c|}
\hline Sample & $\max C D R$ & Obs & Mean & $\begin{array}{l}\text { CDRnodef- } \\
\text { CDRdef }<0\end{array}$ & $\begin{array}{c}\text { p-value } \\
\text { CDRnodef- } \\
\text { CDRdef different } \\
\text { from } 0 \\
\end{array}$ & $\begin{array}{l}\text { CDRnodef- } \\
\text { CDRdef }>0\end{array}$ \\
\hline Full sample & $\begin{array}{c}\text { no default } \\
\text { default }\end{array}$ & $\begin{array}{c}625 \\
20\end{array}$ & $\begin{array}{l}0.0578 \\
0.1079\end{array}$ & 0.0015 & 0.0030 & 0.9985 \\
\hline $\begin{array}{l}\text { Countries having at } \\
\text { least one default }\end{array}$ & $\begin{array}{c}\text { no default } \\
\text { default }\end{array}$ & $\begin{array}{c}309 \\
20\end{array}$ & $\begin{array}{l}0.0511 \\
0.1079\end{array}$ & 0.0007 & 0.0014 & 0.9993 \\
\hline Argentina & $\begin{array}{c}\text { no default } \\
\text { default }\end{array}$ & $\begin{array}{c}31 \\
2\end{array}$ & $\begin{array}{l}0.0452 \\
0.1330\end{array}$ & 0.0017 & 0.0034 & 0.9983 \\
\hline Nigeria & $\begin{array}{c}\text { no default } \\
\text { default }\end{array}$ & $\begin{array}{c}31 \\
2\end{array}$ & $\begin{array}{l}0.0614 \\
0.1340\end{array}$ & 0.0697 & 0.1394 & 0.9303 \\
\hline Peru & $\begin{array}{c}\text { no default } \\
\text { default }\end{array}$ & $\begin{array}{c}23 \\
2\end{array}$ & $\begin{array}{l}0.0567 \\
0.0316\end{array}$ & 0.6649 & 0.6702 & 0.3351 \\
\hline Russia & $\begin{array}{l}\text { no default } \\
\text { default }\end{array}$ & $\begin{array}{c}11 \\
2\end{array}$ & $\begin{array}{l}0.0641 \\
0.1828\end{array}$ & 0.0260 & 0.0521 & 0.9740 \\
\hline Uruguay & $\begin{array}{c}\text { no default } \\
\text { default }\end{array}$ & $\begin{array}{c}19 \\
2\end{array}$ & $\begin{array}{l}0.0322 \\
0.0200\end{array}$ & 0.6885 & 0.6230 & 0.3115 \\
\hline South Africa & $\begin{array}{c}\text { no default } \\
\text { default }\end{array}$ & $\begin{array}{c}27 \\
2\end{array}$ & $\begin{array}{l}0.0140 \\
0.0208\end{array}$ & 0.2348 & 0.4696 & 0.7652 \\
\hline
\end{tabular}

Notes: CDR is defined as cumulated drop since last peak, measured as $\mathrm{CDR}_{\mathrm{t}}=\max \left\{\mathrm{y}_{\mathrm{t}-\mathrm{s}}\right\}_{\mathrm{s}=0, \ldots, \mathrm{t}}-\mathrm{y}_{\mathrm{t}}$, where $\mathrm{y}_{\mathrm{t}}$ represents $\log$ of GDP, and s represents the periods since last peak. 
Table 11. Current Depth of the Recession and Growth after Default

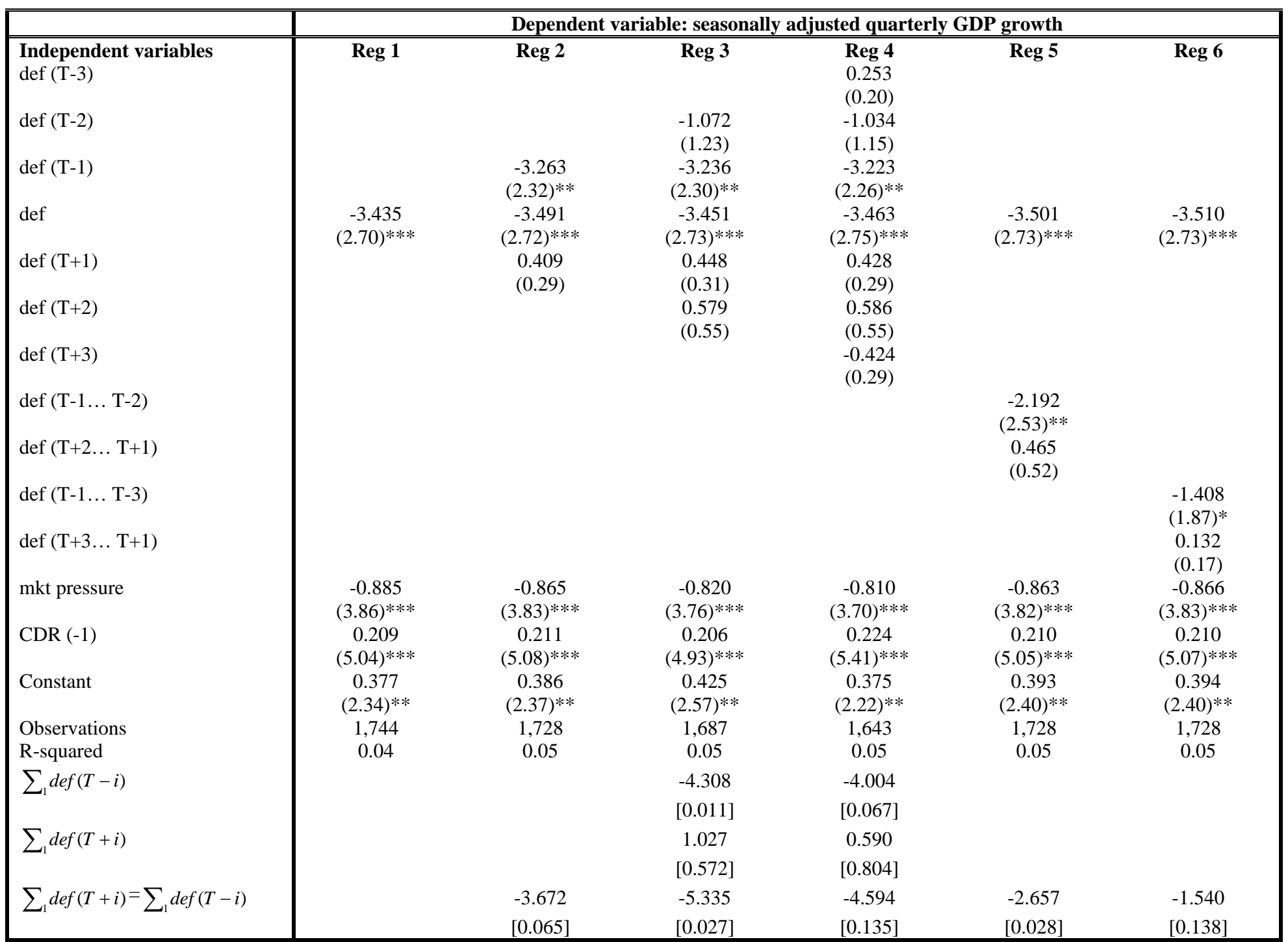

Notes: All regressions include country fixed effects. Robust t statistics in parentheses, * significant at 10\%; ** significant at 5\%; *** significant at $1 \%$. P-value of F-tests in brackets. . 


\section{Table 12. Default and Long-Run Growth}

\section{Group 1}

\begin{tabular}{|cccc|}
\hline wbcode & cyname & year & quarter \\
\hline \hline MEX & Mexico & 1982 & 3 \\
PAK & Pakistan & 1998 & 2 \\
PER & Peru & 1980 & 1 \\
PHL & Philippines & 1983 & 4 \\
RUS & Russia & 1991 & 4 \\
ZAF & South Africa & 1989 & 4 \\
\hline
\end{tabular}

Notes: Group 1 are default episodes where growth in the four periods after the default was below growth in the four periods before the default (so if default is at time t, this group contains all observations where $(G D P(t+5)-G D P(t+1)) / G D P(t+1)<G D P(t-1)-G D P(t-5)) / G D P(t-5))$.

\section{Group 2}

\begin{tabular}{|c|c|c|c|}
\hline wbcode & cyname & year & quarter \\
\hline DOM & $\begin{array}{l}\text { Dominican } \\
\text { Republic }\end{array}$ & 1982 & 4 \\
\hline IDN & Indonesia & 1998 & 2 \\
\hline NGA & Nigeria & 1983 & 3 \\
\hline ZAF & South Africa & 1985 & 3 \\
\hline
\end{tabular}

Notes: Group 2 contains all episodes in where growth in the four periods after the default was higher than growth in the four periods before the default but below long-run growth (so if default is at time t, this group contains all observations where LRGR $>(G D P(t+5)-$ $\mathrm{GDP}(\mathrm{t}+1)) / \mathrm{GDP}(\mathrm{t}+1)>\mathrm{GDP}(\mathrm{t}-1)-\mathrm{GDP}(\mathrm{t}-5)) / \mathrm{GDP}(\mathrm{t}-5))$. Where long run growth (LRGR) is annual growth computed over the whole sample.

\section{Group 3}

\begin{tabular}{|cccc|}
\hline wbcode & cyname & year & quarter \\
\hline \hline ARG & Argentina & 1982 & 1 \\
ARG & Argentina & 2001 & 4 \\
CHL & Chile & 1983 & 1 \\
ECU & Ecuador & 1999 & 3 \\
NGA & Nigeria & 1986 & 3 \\
PER & Peru & 1983 & 1 \\
RUS & Russia & 1998 & 4 \\
UKR & Ukraine & 1998 & 3 \\
URY & Uruguay & 1990 & 1 \\
URY & Uruguay & 2003 & 2 \\
\hline
\end{tabular}

Notes: Group 3 contains all episodes in where growth in the four periods after the default was higher than growth in the four periods before the default and also higher long-run growth (so if default is at time t, this group contains all observations where $\mathrm{LRGR}<(\mathrm{GDP}(\mathrm{t}+5)-$ $\mathrm{GDP}(\mathrm{t}+1)) / \mathrm{GDP}(\mathrm{t}+1)>\mathrm{GDP}(\mathrm{t}-1)-\mathrm{GDP}(\mathrm{t}-5)) / \mathrm{GDP}(\mathrm{t}-5))$. Where long run growth (LRGR) is annual growth computed over the whole sample. 
Table 13. Long-Run Growth Regressions

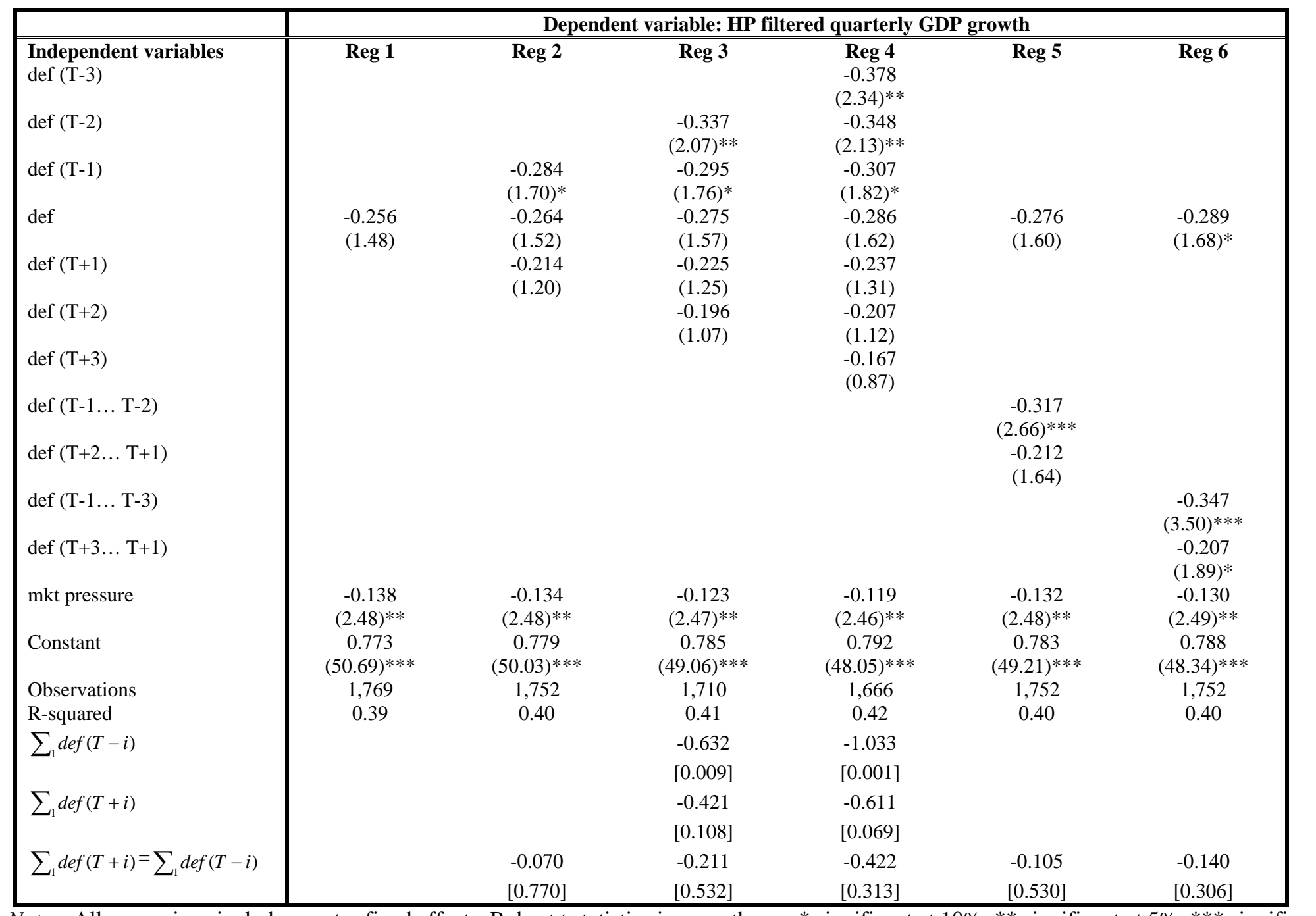

Notes: All regressions include country fixed effects. Robust t statistics in parentheses, * significant at $10 \%$; ** significant at $5 \%$; $* * *$ significant at $1 \%$. P-value of F-tests in brackets. 
Table 14. Default and Unemployment

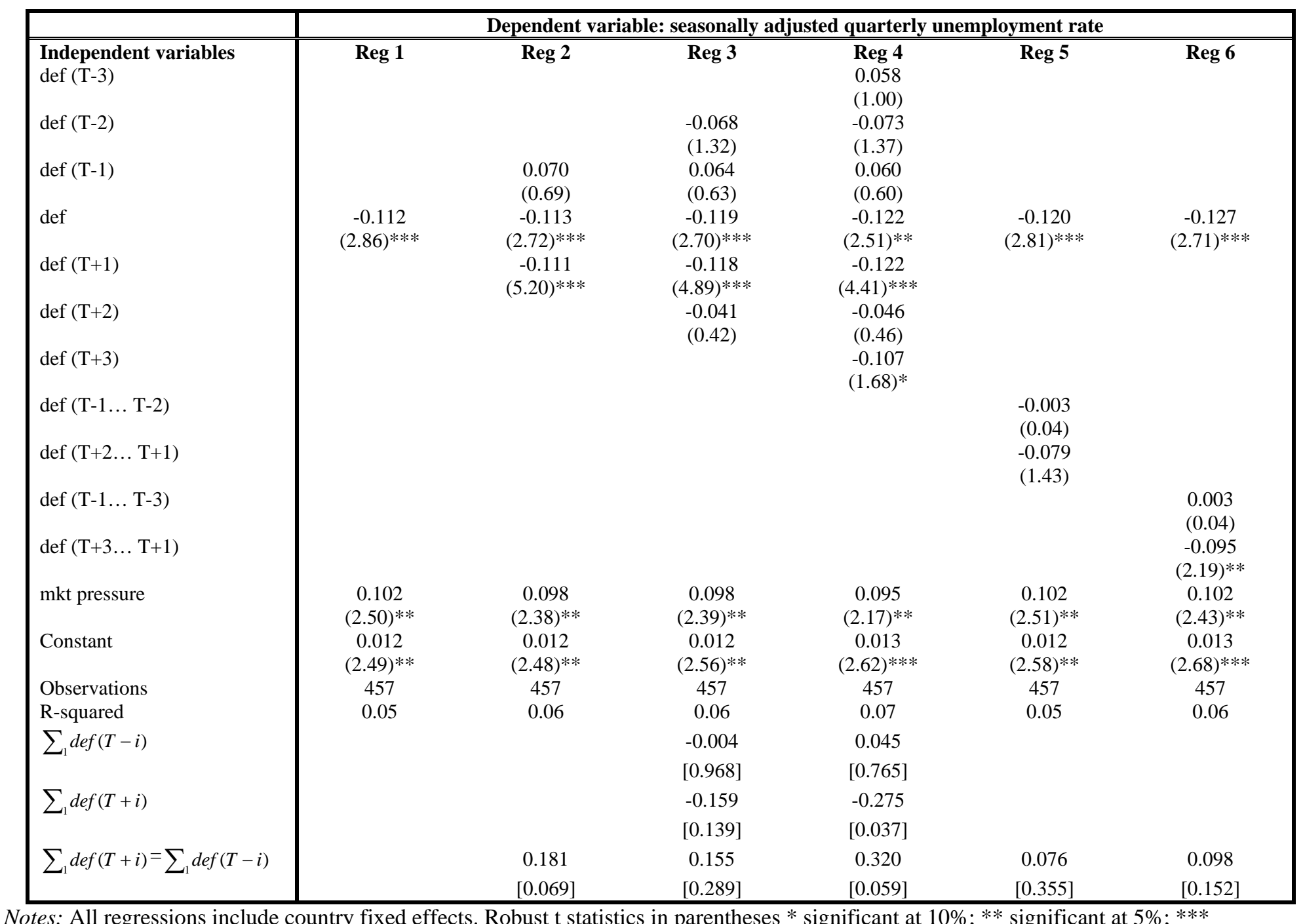

significant at $1 \%$. P-value of F-tests in brackets. 


\section{Appendix}

Table A1. Variable Definition and Sources

Yearly variables

\begin{tabular}{|c|c|c|}
\hline Variable & Definition & Source \\
\hline growth & $\begin{array}{l}\text { GDP per capita growth (annual \%) } \\
\text { Investment share of CGDP (current prices) }\end{array}$ & $\begin{array}{l}\text { World Development Indicators } \\
\text { World Development Indicators }\end{array}$ \\
\hline $\begin{array}{l}\text { pop growth } \\
\text { sec } \\
\text { pop level }\end{array}$ & $\begin{array}{c}\text { Population growth rate } \\
\text { Percentage of secondary school attained in the total pop } \\
\text { Total population }\end{array}$ & $\begin{array}{l}\text { World Development Indicators } \\
\text { Barro and Lee (2000). } \\
\text { World Development Indicators }\end{array}$ \\
\hline gov & $\begin{array}{l}\text { One period lag of general government final } \\
\text { consumption expenditure (annual \% growth) }\end{array}$ & World Development Indicators \\
\hline civil & Index of Civil Rights & Freedom in The World \\
\hline$\Delta \mathrm{tt}$ & Terms of trade (tt) variation, computed as tt-tt(-1) & World Development Indicators \\
\hline openness & Average exports plus imports to GDP (current US\$) & World Development Indicators \\
\hline bank2av1 & Bank Crisis Measure (binary, $1=$ crisis) & Caprio and Kinglebiel (2003) \\
\hline def & $\begin{array}{c}\text { Beginning of Foreign Currency Bank and Bond Debt } \\
\text { Default }\end{array}$ & Standard \& Poor's \\
\hline $\operatorname{def}(+1)$ & Forward of def & \\
\hline $\operatorname{def}(-1)$ & Lag of def & \\
\hline
\end{tabular}

Quarterly variables

\begin{tabular}{|c|c|c|}
\hline Variable & Definition & Source \\
\hline growth & $\begin{array}{l}\text { Real seasonally adjusted GDP growth (\% change). In } \\
\text { order to seasonally adjust the real GDP series, we } \\
\text { proceed in the following way. First, we calculate the } \\
\text { mean of real GDP by country. Next, we obtained the } \\
\text { residuals of a regression of real GDP on quarterly } \\
\text { dummies. Finally, we added the residuals to mean } \\
\text { growth series. We dropped observations where the } \\
\text { absolute value of quarterly GDP growth was greater } \\
\text { than } 30 \text { percent. }\end{array}$ & $\begin{array}{l}\text { International Financial Statistics } \\
\text { and national sources }\end{array}$ \\
\hline def & $\begin{array}{c}\text { Beginning of Foreign Currency Bank and Bond Debt } \\
\text { Default }\end{array}$ & $\begin{array}{l}\text { Global Development Finance } 2003 \\
\text { (Analysis and Statistical Appendix) } \\
\text { and Standard \& Poor’s }\end{array}$ \\
\hline $\begin{array}{l}x(-\mathrm{i}) \\
x(+\mathrm{i})\end{array}$ & $\begin{array}{c}\mathrm{i}^{\text {th }} \text { lag of variable } x \\
\mathrm{i}^{\text {th }} \text { lead of variable } x\end{array}$ & \\
\hline External & Index of external factors & \\
\hline mkt pressure & $\begin{array}{c}\text { High-frequency market pressure index (reserves }+ \\
\text { depreciation weigthed by the inverse of their standard } \\
\text { deviation) }\end{array}$ & International Financial Statistics \\
\hline
\end{tabular}


Table A2. List of Countries and Years Included in the Quarterly Analysis

\begin{tabular}{|c|c|}
\hline Country & Years and quarters \\
\hline Algeria & From 1995:2 to 2005:1 \\
\hline Argentina & From $1970: 2$ to $2005: 4$ \\
\hline Bangladesh & From $2000: 2$ to $2004: 4$ \\
\hline Barbados & From $2000: 2$ to $2005: 3$ \\
\hline Brazil & From 1991:2 to 2002:4 \\
\hline Bulgaria & From $2000: 2$ to $2005: 3$ \\
\hline Chile & From $1980: 2$ to $2002: 4$ \\
\hline Colombia & From $1994: 2$ to $2002: 4$ \\
\hline Cote D’ Ivoire & From 2000:2 to $2003: 4$ \\
\hline Croatia & From $1991: 2$ to $2005: 3$ \\
\hline Cyprus & From 2000:2 to $2005: 3$ \\
\hline Dominican Republic & From $1980: 2$ to $2002: 4$ \\
\hline Ecuador & From 1991:2 to $2002: 4$ \\
\hline Fiji & From $2000: 2$ to $2002: 4$ \\
\hline Hungary & From $1979: 2$ to $2005: 3$ \\
\hline India & From 2000:2 to $2005: 3$ \\
\hline Indonesia & From $1993: 2$ to $2002: 4$ \\
\hline Korea & From $1970: 2$ to $2005: 3$ \\
\hline Luxembourg & From $2000: 2$ to $2005: 3$ \\
\hline Macedonia, FYR & From $2000: 2$ to $2004: 4$ \\
\hline Malawi & From 2000:2 to $2004: 2$ \\
\hline Malaysia & From $1970: 2$ to $2005: 3$ \\
\hline Mexico & From $1970: 2$ to $2005: 3$ \\
\hline Morocco & From 1993:2 to 2002:4 \\
\hline Nigeria & From $1970: 2$ to $2005: 3$ \\
\hline Pakistan & From $1995: 3$ to $2002: 2$ \\
\hline Peru & From $1979: 2$ to $2002: 4$ \\
\hline Philippines & From $1981: 2$ to $2005: 2$ \\
\hline Poland & From $1982: 2$ to $2005: 3$ \\
\hline Russia & From $1991: 2$ to $2002: 4$ \\
\hline Senegal & From 2000:4 to $2003: 4$ \\
\hline South Africa & From $1970: 2$ to $2002: 4$ \\
\hline Thailand & From $1993: 2$ to $2002: 4$ \\
\hline Trinidad y Tobago & From $2000: 2$ to $2004: 4$ \\
\hline Tunisia & From $1970: 2$ to $2005: 3$ \\
\hline Turkey & From $1980: 2$ to $2005: 3$ \\
\hline Ukraine & From $1993: 2$ to $2002: 4$ \\
\hline Uruguay & From $1988: 2$ to $2004: 4$ \\
\hline Venezuela & From $1993: 2$ to $2002: 4$ \\
\hline
\end{tabular}

